\title{
ZUSES
}

Prepared in cooperation with the

Connecticut Department of Energy and Environmental Protection

The Connecticut Streamflow and Sustainable Water Use Estimator: A Decision-Support Tool To Estimate Water Availability at Ungaged Stream Locations in Connecticut

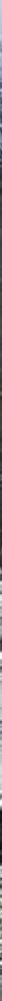

Scientific Investigations Report 2018-5135

US Departiment of the interior U. Geologioal Sungy 
Cover. West Cornwall Covered Bridge spanning the Housatonic River near Cornwall, Connecticut. Photograph by Tracey Thayer, used with permission. 


\section{The Connecticut Streamflow and Sustainable Water Use Estimator: A Decision-Support Tool To Estimate Water Availability at Ungaged Stream Locations in Connecticut}

By Sara B. Levin, Scott A. Olson, Martha G. Nielsen, and Gregory E. Granato

Prepared in cooperation with the

Connecticut Department of Energy and Environmental Protection

Scientific Investigations Report 2018-5135 


\title{
U.S. Department of the Interior \\ RYAN K. ZINKE, Secretary
}

\author{
U.S. Geological Survey \\ James F. Reilly II, Director
}

U.S. Geological Survey, Reston, Virginia: 2018

For more information on the USGS - the Federal source for science about the Earth, its natural and living resources, natural hazards, and the environment-visit https://www.usgs.gov or call 1-888-ASK-USGS.

For an overview of USGS information products, including maps, imagery, and publications,

visit https://store.usgs.gov.

Any use of trade, firm, or product names is for descriptive purposes only and does not imply endorsement by the U.S. Government.

Although this information product, for the most part, is in the public domain, it also may contain copyrighted materials as noted in the text. Permission to reproduce copyrighted items must be secured from the copyright owner.

Suggested citation:

Levin, S.B., Olson, S.A., Nielsen, M.G., and Granato, G.E., 2018, The Connecticut Streamflow and Sustainable Water Use Estimator-A decision-support tool to estimate water availability at ungaged stream locations in Connecticut: U.S. Geological Survey Scientific Investigations Report 2018-5135, 34 p., https://doi.org/10.3133/sir20185135.

ISSN 2328-0328 (online) 


\section{Acknowledgments}

The authors thank Teresa Gannon of the Connecticut Department of Energy and Environmental Protection for supplying water-use data and review of the report. The authors also thank U.S. Geological Survey colleagues Jeremy Newson and Hans Vraga for facilitating the incorporation of water-use data into the StreamStats web application, and Elizabeth Ahearn, Gardner Bent, and Stacey Archfield for their technical reviews. 



\section{Contents}

Acknowledgments ……...................................................................................................................

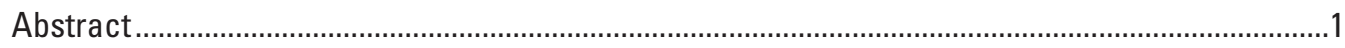

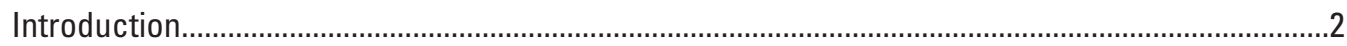

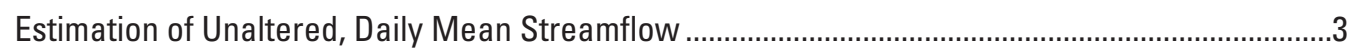

Regional Regression Equations for Estimating Streamflow Quantiles ......................................3

Streamgage Selection and Basin Characteristics ..........................................................

Model Development and Verification ............................................................................

Estimation of Streamflow Time Series by Use of a Reference Streamgage..............................8

Reference Streamgages Included in the Study Area ......................................................8

Selection of a Reference Streamgage for an Ungaged Site ..........................................

Accuracy and Uncertainty of Estimated Unaltered Streamflow ................................................9

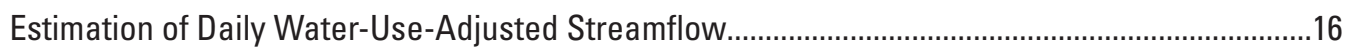

Time-Lagged Streamflow Depletion From Groundwater Withdrawals ....................................16

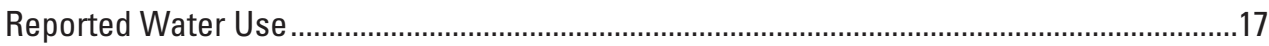

Using the Connecticut Streamflow and Sustainable Water Use Estimator to Estimate

Daily Streamflow and Sustainable Net Withdrawal.........................................................19

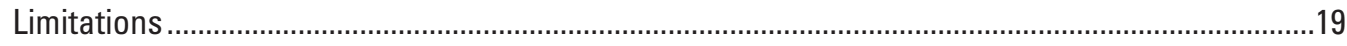

Summary

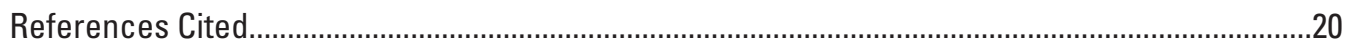

Appendix 1. Reference Streamgages and Periods of Record Used for the Connecticut

Streamflow and Sustainable Water Use Estimator ...........................................................23

Appendix 2. Basin Characteristics Tested for Use in the Regression Equations for

Estimating Streamflow at Ungaged Sites With the Connecticut Streamflow and

Sustainable Water Use Estimator........................................................................................

Appendix 3. Dates of Station Record and Dates of Extended Record for Reference

Streamgages Used by the Connecticut Streamflow and Sustainable Water Use

Estimator.

\section{Figures}

1. Map showing locations of 61 U.S. Geological Survey reference streamgages with drainage basins, including 36 streamgages used for developing regression equations in the Connecticut Streamflow and Sustainable Water Use Estimator, Connecticut and vicinity...

2. Diagram showing translation of a flow-duration curve to a time series of streamflow estimated by the Connecticut Streamflow and Sustainable Water Use Estimator using the QPPQ method..

3. Map showing estimated Pearson $r$ correlation coefficients for streamgages in the study area with the logarithm of daily mean streamflow at the U.S. Geological Survey streamgages $A, 01208990$, Saugatuck River near Redding, Conn., and $B, 01194000$, Eightmile River at North Plain, Conn., from October 1, 1960, to September 30, 2015...

4. Boxplots showing the distributions of $A$, Nash-Sutcliffe efficiency and $B$, normalized root-mean-square error for observed and estimated daily mean streamflow at 61 U.S. Geological Survey streamgages from October 1, 1960, to September 30, 2015, Connecticut and vicinity ..... 
5. Graphs showing observed and estimated $A-B$, daily mean streamflow and $C-D$, monthly mean streamflow for U.S. Geological Survey streamgages 01192600 , South Branch Salmon Brook at Buckingham, Conn., and 01121000, Mount Hope River near Warrenville, Conn., from October 1, 1960, to September 30, 2015.

6. Plots showing $A$, the observed and estimated mean of the monthly mean streamflow and $B$, the percent error of the estimated mean of the monthly mean streamflow for 61 U.S. Geological Survey streamgages used as reference streamgages in the Connecticut Streamflow and Sustainable Water Use Estimator, from October 1, 1960, to September 30, 2015, Connecticut and vicinity.

7. Schematic diagram of the process used to compute 95-percent prediction intervals for daily unaltered streamflows estimated by the Connecticut Streamflow and Sustainable Water Use Estimator

8. Boxplots showing the coverage ratio for prediction intervals for daily and monthly mean time series of estimated unaltered streamflow at 61 reference streamgages used in the Connecticut Streamflow and Sustainable Water Use Estimator, from October 1, 1960, to September 30, 2015, Connecticut and vicinity

9. Map showing locations of permitted water withdrawals and wastewater discharges in central and eastern Connecticut used in the Connecticut Streamflow and Sustainable Water Use Estimator

\section{Tables}

1. Streamflow for selected exceedance probabilities for streamgages used in the development of the Connecticut Streamflow and Sustainable Water Use Estimator ......3

2. Number of streamgages, regression methods, explanatory variables, estimated regression coefficients, and regression diagnostics for the regression equations for estimating daily mean streamflow at selected exceedance probabilities in ungaged, unaltered streams in Connecticut and vicinity

3. Basin characteristics used to develop the regression equations for estimating daily mean streamflow at selected exceedance probabilities for ungaged, unaltered streams in Connecticut and vicinity

4. Ranges of explanatory variables used in the development of the regression equations for estimating daily mean streamflow at selected exceedance probabilities for ungaged, unaltered streams in Connecticut and vicinity 


\section{Conversion Factors}

U.S. customary units to International System of Units

\begin{tabular}{lcl}
\hline \multicolumn{1}{c}{ Multiply } & By & \multicolumn{1}{c}{ To obtain } \\
\hline inch (in.) & Length & \\
foot (ft) & 25.4 & millimeter $(\mathrm{mm})$ \\
mile (mi) & 0.3048 & meter $(\mathrm{m})$ \\
\hline & 1.609 & kilometer $(\mathrm{km})$ \\
\hline square mile $\left(\mathrm{mi}^{2}\right)$ & Area & \\
\hline & 2.590 & square kilometer $\left(\mathrm{km}^{2}\right)$ \\
\hline cubic foot per second $\left(\mathrm{ft}^{3} / \mathrm{s}\right)$ & Flow rate & \\
inch per hour $(\mathrm{in} / \mathrm{h})$ & 0.02832 & cubic meter per second $\left(\mathrm{m}^{3} / \mathrm{s}\right)$ \\
\hline
\end{tabular}

Temperature in degrees Celsius $\left({ }^{\circ} \mathrm{C}\right)$ may be converted to degrees Fahrenheit $\left({ }^{\circ} \mathrm{F}\right)$ as follows:

$$
{ }^{\circ} \mathrm{F}=\left(1.8 \times{ }^{\circ} \mathrm{C}\right)+32 .
$$

Temperature in degrees Fahrenheit $\left({ }^{\circ} \mathrm{F}\right)$ may be converted to degrees Celsius $\left({ }^{\circ} \mathrm{C}\right)$ as follows:

$$
{ }^{\circ} \mathrm{C}=\left({ }^{\circ} \mathrm{F}-32\right) / 1.8 \text {. }
$$

\section{Datum}

Vertical coordinate information is referenced to the North American Vertical Datum of 1988 (NAVD 88).

Horizontal coordinate information is referenced to the North American Datum of 1983 (NAD 83).

Elevation, as used in this report, refers to distance above the vertical datum.

\section{Abbreviations}

CT DEEP Connecticut Department of Energy and Environmental Protection

CT SSWUE Connecticut Streamflow and Sustainable Water Use Estimator

GIS geographic information system

GUI graphical user interface

NRMSE normalized root-mean-square error

NSE Nash-Sutcliffe efficiency

RG reference streamgage

USGS U.S. Geological Survey 



\title{
The Connecticut Streamflow and Sustainable Water Use Estimator: A Decision-Support Tool To Estimate Water Availability at Ungaged Stream Locations in Connecticut
}

\author{
By Sara B. Levin, Scott A. Olson, Martha G. Nielsen, and Gregory E. Granato
}

\section{Abstract}

Freshwater streams in Connecticut are subject to many competing demands, including public water supply; agricultural, commercial, and industrial water use; and ecosystem and habitat needs. In recent years, drought has further stressed Connecticut's water resources. To sustainably allocate and manage water resources among these competing uses, Federal, State, and local water-resource managers require data and modeling tools to estimate the water availability at a variety of temporal and spatial scales for planning purposes. The Connecticut Streamflow and Sustainable Water Use Estimator (CT SSWUE), developed by the U.S. Geological Survey in cooperation with the Connecticut Department of Energy and Environmental Protection, is a decision-support tool for estimating daily unaltered streamflow and sustainable water use at ungaged sites in Connecticut.

The CT SSWUE estimates unaltered daily mean streamflow and water-use-adjusted streamflow for the period from October 1, 1960, to September 30, 2015, and the monthly sustainable net withdrawal at ungaged sites in Connecticut. Unaltered streamflow is the estimated daily mean streamflow in a drainage basin in the absence of any water withdrawals or wastewater discharges and with minimal human development. Sustainable net withdrawal is the maximum net withdrawal (withdrawal minus wastewater discharges) that can be drawn from a basin without critically depleting the water available through natural streamflow patterns. Sustainable net withdrawal is defined for this study as the difference between the unaltered daily mean streamflow and a user-defined target minimum streamflow.

Weighted least squares and Tobit regression techniques were used to develop equations for estimating streamflow at ungaged sites at 19 streamflow quantiles with exceedance probabilities ranging from 0.005 to 99.995 percent. Regressions were based on streamflow quantiles and basin characteristics from 36 reference streamgages in and around Connecticut. Four basin characteristics - drainage area, mean of the soil permeability, mean of the average annual precipitation, and ratio of the length of streams that overlay sand and gravel deposits to the total length of streams in the basin - are used as explanatory variables in the equations. At an ungaged site, interpolation between the streamflow quantiles estimated from the regression equations produces a continuous flow-duration curve. A time series of daily mean streamflow at an ungaged site is then estimated by assuming that for each day, the streamflow quantile occurs on the same date at both a reference streamgage and the ungaged site.

In a remove-one cross validation, estimated unaltered daily mean streamflow agreed well with observed values at reference streamgages, with a few exceptions. Nash Sutcliffe efficiency ranged from -0.43 to 0.97 with a median value of 0.88 . The normalized root-mean-square error ranged from 16.6 to 120.4 percent with a median value of 34.5 percent.

An empirical method for estimating 95-percent prediction intervals for unaltered daily and monthly mean streamflow was developed and tested by using the cross-validation data. Prediction intervals for unaltered daily mean streamflow at the cross-validation reference streamgages performed well in most cases. Gaged streamflow values from the cross-validation data fell within the prediction intervals a median 96.6 percent of the time for daily mean time series and 93.9 percent of the time for monthly mean time series.

The CT SSWUE computes water-use-adjusted streamflow using spatially referenced water-use information provided by the Connecticut Department of Energy and Environmental Protection. Available water-use information included permitted and registered water withdrawals and permitted wastewater discharges during 1998 to 2015 for the Thames River Basin and central coastal drainage basins. Water-use information was incorporated into the U.S. Geological Survey StreamStats web application for Connecticut and can be used for computing water-use-adjusted streamflow and sustainable net withdrawal at selected points of interest. Altered daily streamflow is computed by applying average daily withdrawals and wastewater discharges to the water balance equation. Average daily surface water withdrawals and wastewater discharges are applied directly to the daily water balance equation. Time-lagged alterations on streamflow from groundwater withdrawals or wastewater discharges are estimated by using a response-coefficient method developed from results of previously published, calibrated groundwater models. 


\section{Introduction}

Given competing demands for water and a long history of development in Connecticut, water-resource managers need data and modeling tools to better understand the water resources of many drainage basins in the State. The Connecticut General Assembly established a Water Planning Council in 2001 to address issues involving water companies, water resources, and State policies regarding the future of the State's drinking water supply. State legislation requires the Water Planning Council to develop a State water plan that would balance the needs of public water supply, economic development, recreation, and ecological health (Public Act 14-163). The plan was submitted to the Connecticut Legislature on January 24, 2018. In 2005, the Connecticut General Assembly passed Public Act 05-142 (CGS §26-141a and b), which required the Connecticut Department of Energy and Environmental Protection (CT DEEP) to update standards for maintaining minimum streamflow targets in rivers and streams. The act required these standards to balance river and stream ecology, wildlife, and recreation while providing for public health, flood control, industry, public utilities, water supply, public safety, agriculture, and other lawful uses of water. In 2011, the State of Connecticut adopted new Stream Flow Standards and Regulations (RCSA §26-141b).

Balancing human needs for water with the needs for water in sustaining healthy ecosystems requires an understanding of the natural streamflow at a given site and the human alterations to that streamflow. The seasonal and annual variability of streamflow in Connecticut can complicate plans for sustainable water management. Daily streamflow can vary over several orders of magnitude throughout the year, with the lowest streamflow occurring during the summer months, when water withdrawals are typically the highest. This combination of low flows and large water withdrawals can negatively affect aquatic communities and streamflow habitats (Poff and Zimmerman, 2010; Armstrong and others, 2011).

Since 2005, when the General Assembly required CT DEEP to update streamflow standards, the U.S. Geological Survey (USGS), in cooperation with CT DEEP, conducted several studies that contributed to planning and management of Connecticut water resources (Ahearn, 2008, 2010). As part of the ongoing process of implementing streamflow standards, new methods and tools are needed for describing and quantifying streamflow and sustainable water use. The U.S. Geological Survey, in cooperation with CT DEEP, developed a tool for the estimation of water availability by leveraging work done by the USGS for estimating water availability in Massachusetts (Archfield and others, 2010) and as part of the USGS StreamStats program (U.S. Geological Survey, 2017b). The Connecticut Streamflow and Sustainable Water Use Estimator (CT SSWUE) is a decision-support tool that estimates unaltered and water-use-adjusted streamflow and computes the sustainable net withdrawal at ungaged sites in Connecticut under various water-use scenarios.
Methods for estimating unaltered daily mean streamflow were developed and documented by Archfield and others (2010) and have been replicated in other statewide or regional applications (Stuckey and others, 2012; Gazoorian, 2015; Lorenz and Ziegeweid, 2016; Stuckey, 2016). The flow-duration curve for an ungaged basin in Connecticut can be estimated by using regression equations developed and described in this report. The estimated flow-duration curve can be transformed into a time series of daily mean streamflow by using the QPPQ method (Fennessey, 1994), which uses the time series at a reference streamgage site to assign a date to the estimated streamflow quantiles at the ungaged site. The QPPQ method has been successfully used in several studies (Hughes and Smakhtin, 1996; Smakhtin, 1999; Smakhtin and Masse, 2000; Mahamoud, 2008; Shu and Ouarda, 2012; Linhart and others, 2013). An empirical method for estimating prediction intervals for estimates of unaltered daily and monthly mean streamflow (Farmer and Levin, 2018) was also tested and implemented in this study.

Natural streamflow patterns are affected by upstream surface-water and groundwater withdrawals and wastewater discharges within the basin. The CT SSWUE can compute water-use-adjusted streamflow time series in order to assess the potential effects of a water-use scenario across the range of historical hydrologic conditions. Reported water withdrawals and wastewater discharges during the years 1998 to 2015 were compiled from registered and permitted sources from the Thames River Basin and central coastal basins for use with the CT SSWUE (see the section "Reported Water Use"). Users may add additional withdrawal or wastewater discharge information for the basin of interest for scenario testing. Water-use information was entered into the USGS StreamStats web application (U.S. Geological Survey, 2012), which provides a monthly water-use summary for the basin of interest.

Users may input a minimum monthly streamflow target for the basin of interest in order to estimate the sustainable net withdrawal. For the purpose of this report, sustainable net withdrawal is defined as the maximum amount of water that can be withdrawn from a basin during the drought of record, without causing the streamflow to be depleted past the minimum flow target. The target minimum streamflow can be a percentage of unaltered flow, or it can be a specific monthly flow set by the user.

This report documents the data and methods used to develop the CT SSWUE, which estimates streamflow and sustainable net withdrawal at ungaged sites in Connecticut. The report explains the multistep process of estimating unaltered, daily mean streamflow, including the development of regression equations for 19 streamflow quantiles, the interpolation of the regressed streamflow quantiles into a continuous flowduration curve, the transformation of the flow-duration curve into a time series of daily mean streamflows using the QPPQ method, and the process used to estimate 95-percent prediction intervals for unaltered daily and monthly mean streamflow. The report then documents the water-use data compiled for use with the CT SSWUE and the method for calculating 
water-use-adjusted streamflow. The graphical user interface (GUI) and the limitations of the application of the CT SSWUE are also described.

\section{Estimation of Unaltered, Daily Mean Streamflow}

The CT SSWUE estimates unaltered, daily mean streamflow for the 55 water-year ${ }^{1}$ period from October 1, 1960, through September 30, 2015. The multistep process used to estimate a time series of unaltered daily mean streamflow involves several statistical and geostatistical methods. In the first step, regression equations are used to estimate streamflow at selected quantiles along the flow-duration curve. A continuous flow-duration curve is produced by interpolating between the regression-based quantiles. Next, the QPPQ method (Fennessey, 1994) is used to transform the flow-duration curve into a daily time series using a reference streamgage that is hydrologically similar to the ungaged basin and has minimally altered streamflow.

\section{Regional Regression Equations for Estimating Streamflow Quantiles}

Regional equations to estimate streamflow quantiles for an ungaged site with minimal streamflow alteration were developed by using streamflow records from selected streamgages and their respective physical and climatic basin characteristics. Regression equations relating basin characteristics to streamflow were developed for exceedance probabilities of $0.005,0.4,1,5,10,15,20,30,40,50,60,70,80$, $85,90,95,99,99.6$, and 99.995 percent. The intermediary streamflow quantiles are determined by interpolation to obtain a continuous flow-duration curve. The CT SSWUE transforms each exceedance probability in the flow-duration curve to a normal Z-score by using equation 26.2.23 documented by Abramowitz and Stegun (1964) and linearly interpolates the log-transformed streamflow quantiles from the regression equations across the Z-scores. The Z-score transformation is needed in order to linearize the high degree of curvature at the high and low ends of the flow-duration curve. Log-linear interpolation of streamflow quantiles without this transformation can exhibit bias at high and low flows (Archfield and others, 2012).

\section{Streamgage Selection and Basin Characteristics}

Streamgages with minimally altered flow in Connecticut and adjacent, physiographically similar areas in Massachusetts, Rhode Island, and New York were considered as

\footnotetext{
${ }^{1}$ A water year extends from October 1 to September 30 and is designated by the calendar year in which it ends.
}

potential streamgages for this study. Of the sites considered, 36 streamgages were selected for use in the development of the regression equations for estimating streamflow quantiles (fig. 1; appendix 1). The selection criteria for inclusion in the regression equation development required the streamgage to have a minimum of 15 water years of complete record and the basin to be unaffected by appreciable water withdrawals, wastewater discharges, and streamflow regulation resulting in more than a diurnal fluctuation in streamflow. To accurately characterize the lowest streamflows, the streamgages were also required to be active through the historic drought of the 1960s (Weiss, 1991). The 36 streamgages selected for use in regression development had from 15 to 103 water years of daily, mean streamflow observations. The streamgages selected are spatially well distributed in and near Connecticut (fig. 1).

Streamflow quantiles for each of the streamgages were computed by ranking the daily streamflows and computing the exceedance probability (Vogel and Fennessey, 1994). Streamflow quantiles were determined at the 0.005-, 0.4-, 1-, 5-, 10-, 15-, 20-, 30-, 40-, 50-, 60-, 70-, 80-, 85-, 90-, 95-, 99-, 99.6-, and 99.995-percent exceedance probabilities (table 1). Several of the streamgages shown in table 1 did not have records long enough for estimating the 0.005 - and 99.995-percent exceedance probabilities. Equations for these two streamflow quantiles used only the 16 sites that had sufficiently long streamflow records for computing the exceedance probabilities.

Table 1. Streamflow for selected exceedance probabilities for streamgages used in the development of the Connecticut Streamflow and Sustainable Water Use Estimator.

[Table available for download at https://doi.org/10.3133/sir20185135]

A total of 128 physical and climatic basin characteristics (appendix 2) were compiled for the initial explanatory analysis of potential variables in the regression equations. The basin characteristics included variables describing land-use type, terrain, infiltration, basin and stream morphology, and climate. The source datasets of the basin characteristics are shown in appendix 2. Location coordinates were converted to the Connecticut State Plane Coordinate System in feet prior to calculation of basin characteristics.

The geographic information system (GIS) dataset of surficial geology (sand and gravel deposits) required some manipulation to create a uniform GIS dataset that covered the entire study area. Surficial geology datasets were unique to each State and classified sand and gravel deposits differently. Each State's surficial geology dataset was modified to be similar to Connecticut's stratified drift dataset (Connecticut Department of Environmental Protection, 2009). For Rhode Island, the State's glacial deposits dataset (Rhode Island Geographic Information System, 1989) was edited, and areas attributed as "water," "bedrock," "till," and "unknown" were removed. For New York, areally applicable surficial geology datasets (Cadwell and others, 1986) were obtained, and areas attributed as "water," "artificial fill," "swamp deposits," "till," and "bedrock" - features that were not sand and gravel 


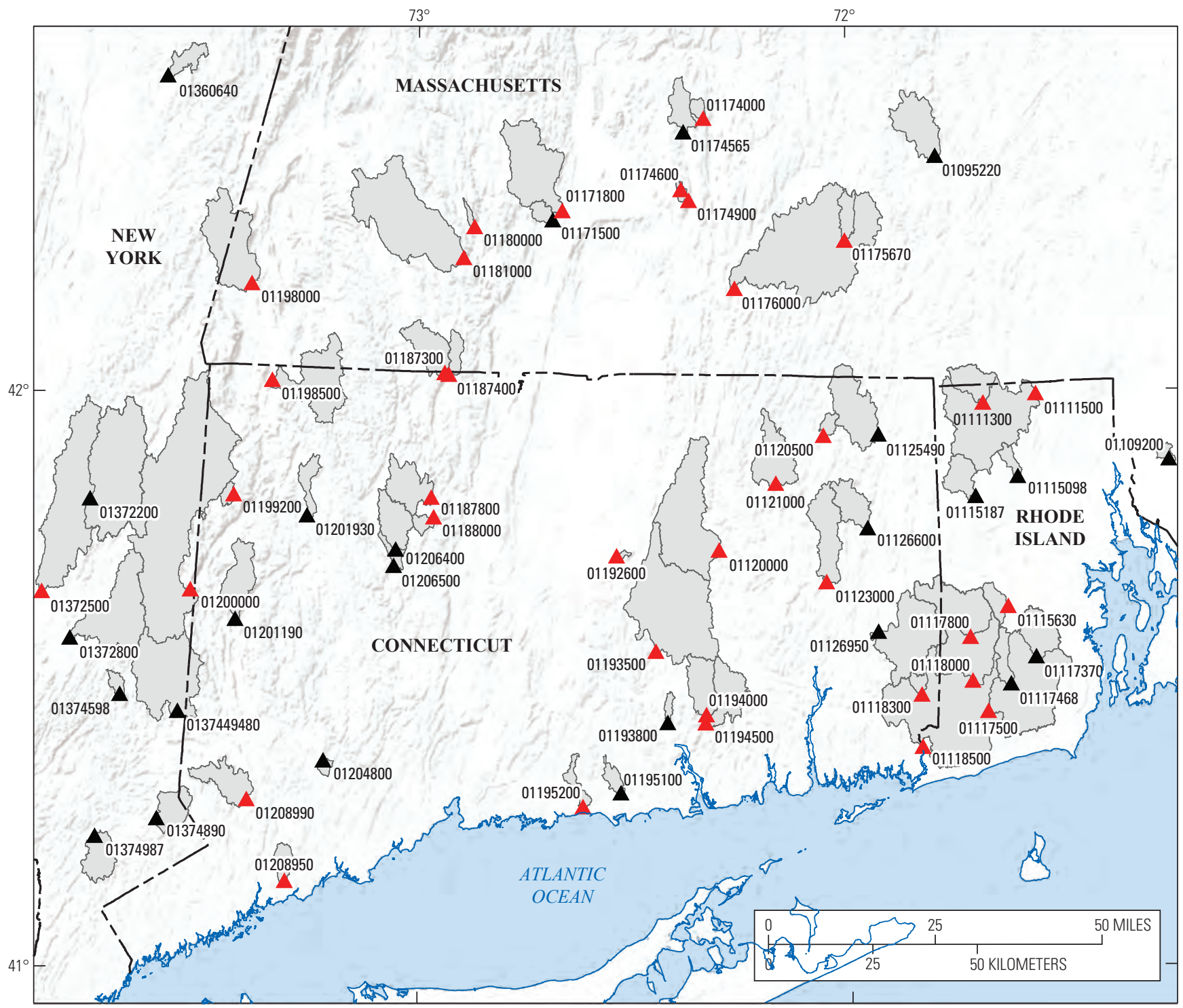

Base from Esri, U.S. Geological Survey, and National Oceanic and Atmospheric Administration digital data, Esri State boundary

1:3,000,000, 2013, and Esri World Terrain, 1:1,000,000, 2017

Connecticut State Plane projection, North American Datum of 1983

Copyright 2017 Esri and its licensors

\section{EXPLANATION}

Streamgage drainage basin

- Streamgage used as a reference streamgage and used to develop regression equations with U.S. Geological Survey streamgage number

- Streamgage used as a reference streamgage with U.S. Geological Survey streamgage number

Figure 1. Locations of 61 U.S. Geological Survey reference streamgages with drainage basins, including 36 streamgages used for developing regression equations in the Connecticut Streamflow and Sustainable Water Use Estimator, Connecticut and vicinity. 
deposits - were removed. For Massachusetts, two surficial geology datasets were used. Because the higher resolution dataset $(1: 24,000)$ did not cover part of the study area, the lower resolution $(1: 250,000)$ dataset (U.S. Geological Survey, 1999, 2015) was substituted in the missing areas. Glacial stratified deposits as well as alluvium and other postglacial deposits of sand and gravel were extracted to make a dataset similar to that of Connecticut. The datasets representing sand and gravel deposits for each State were then merged for use in regression equation development.

The ratio of the length of streams that overlay sand and gravel deposits to the total length of streams in the basin was computed as a potential explanatory variable (appendix 2). The length of streams in the basin was determined by using the National Hydrography Dataset (U.S. Geological Survey, 2017a) flowlines attribute with pipelines and coastline removed. These flowlines were intersected with the GIS dataset of sand and gravel deposits described previously.

\section{Model Development and Verification}

Regression equations were developed for estimating streamflow at the 0.005-, 0.4-, 1-,5-, 10-, 15-, 20-, 30-, 40-, 50-, 60-, 70-, 80-, 85-, 90-, 95-, 99-, 99.6-, and 99.995-percent exceedance probabilities (table 1), and the 128 basin characteristics (appendix 2) were used as potential explanatory variables. The logarithms of the variables were computed to help linearize the relations between quantiles and characteristics. Regression equations for most streamflow quantiles were developed by using weighted least squares regression techniques (table 2). Because several streamgages had streamflows of zero cubic feet per second $\left(\mathrm{ft}^{3} / \mathrm{s}\right)$ for the 99- and 99.6-percent exceedance probabilities, and because the regressions were done on the logarithms of variables, the regression analyses for these two exceedance probabilities were done by using the Tobit regression model, which treats streamflow values of zero cubic feet per second as censored values. Weights used in the weighted least square regression analysis were computed as the ratio of number of days of daily mean flow to the average number of days of flow of the 16 or 36 streamgages used in each regression analysis.

The regression results provide equations for estimating the values of dependent variables from one or more independent variables. The regression equations take the general form

$$
\log _{10} Y_{P}=b_{0}+b_{1} X_{1}+b_{2} X_{2}+\ldots+b_{j} X_{j}
$$

where

$$
\begin{array}{cl}
\log _{10} Y_{P} & \begin{array}{r}
\text { is the logarithm of the magnitude of the daily } \\
\text { mean streamflow having an exceedance } \\
\text { probability of } P \text { percent, }
\end{array} \\
X_{1} \text { to } X_{j} & \begin{array}{r}
\text { are the basin characteristics, and } \\
\text { are coefficients developed from the regression } \\
b_{0} \text { to } b_{j}
\end{array} \\
\text { analysis. }
\end{array}
$$

Since transformations to the explanatory and response variables are logarithmic, equation 1 can be manipulated to take the form

$$
Y_{P}=10^{b_{0}} X_{1}^{b_{1}} X_{2}^{b_{2}} \ldots X_{j}^{b_{j}} .
$$

The statistical software SAS (SAS Institute Inc., 2009) was used to develop the regression equations. Stepwise regression was used to narrow the 128 basin characteristics to a smaller pool of potentially significant basin characteristics. The final set of explanatory variables in the equations was chosen according to the goodness of fit of individual regression equations and the overall ability of the group of regression equations to produce a monotonic flow-duration curve. Daily streamflows are complex, and physical and climatic processes affect parts of the flow-duration curve differently; hence, over the range of the flow-duration curve, different variables are related to different streamflow quantiles. Regression equations for streamflow quantiles developed independently from each other and with different sets of explanatory variables may not produce a flow-duration curve in which streamflow continuously decreases with increasing exceedance probability. In order to enforce the monotonic structure of the flow-duration curve, a consistent set of explanatory variables was chosen across most of the streamflow quantiles. Although most regression coefficients in the regression equations were significantly different from zero at the 0.05 significance level, others were allowed to exceed the 0.05 significance level in order to retain consistency across the regression equations and produce a monotonic relation of streamflow to exceedance probability.

Explanatory variables used in the final suite of regression equations include drainage area in square miles, average annual precipitation in inches, mean soil permeability in inches per hour, and the ratio of the lengths of streams in the basin overlaying sand and gravel deposits to the total length of streams (tables 2 and 3). Because basin characteristics affect high and low streamflow quantiles in different ways, the full set of selected basin characteristics was not used in every regression equation. Drainage area was used as an explanatory variable in all the equations. For all streamflow exceedance probabilities except the 99.995-percent probability, the basinwide mean of the soil permeability in inches per hour (U.S. Geological Survey, 1995) was used in the equations. For streamflow exceedance probabilities from 0.005 to 15 percent, average annual precipitation from 1981 to 2010, in inches (PRISM Climate Group, 2012c), was included in the equation. For streamflow exceedance probabilities from 20 to 99.995 percent, the ratio of the length of streams in the basin that overlay sand and gravel deposits to the total length of streams in the basin was included in the regression equation -1.0 is added to the ratio before it is applied to the regression equation.

The coefficient of determination $\left(R^{2}\right)$ for the 19 regression equations ranged from 0.761 to 0.997 , and the root-meansquare error ranged from 0.036 to 0.559 (table 2). Model 


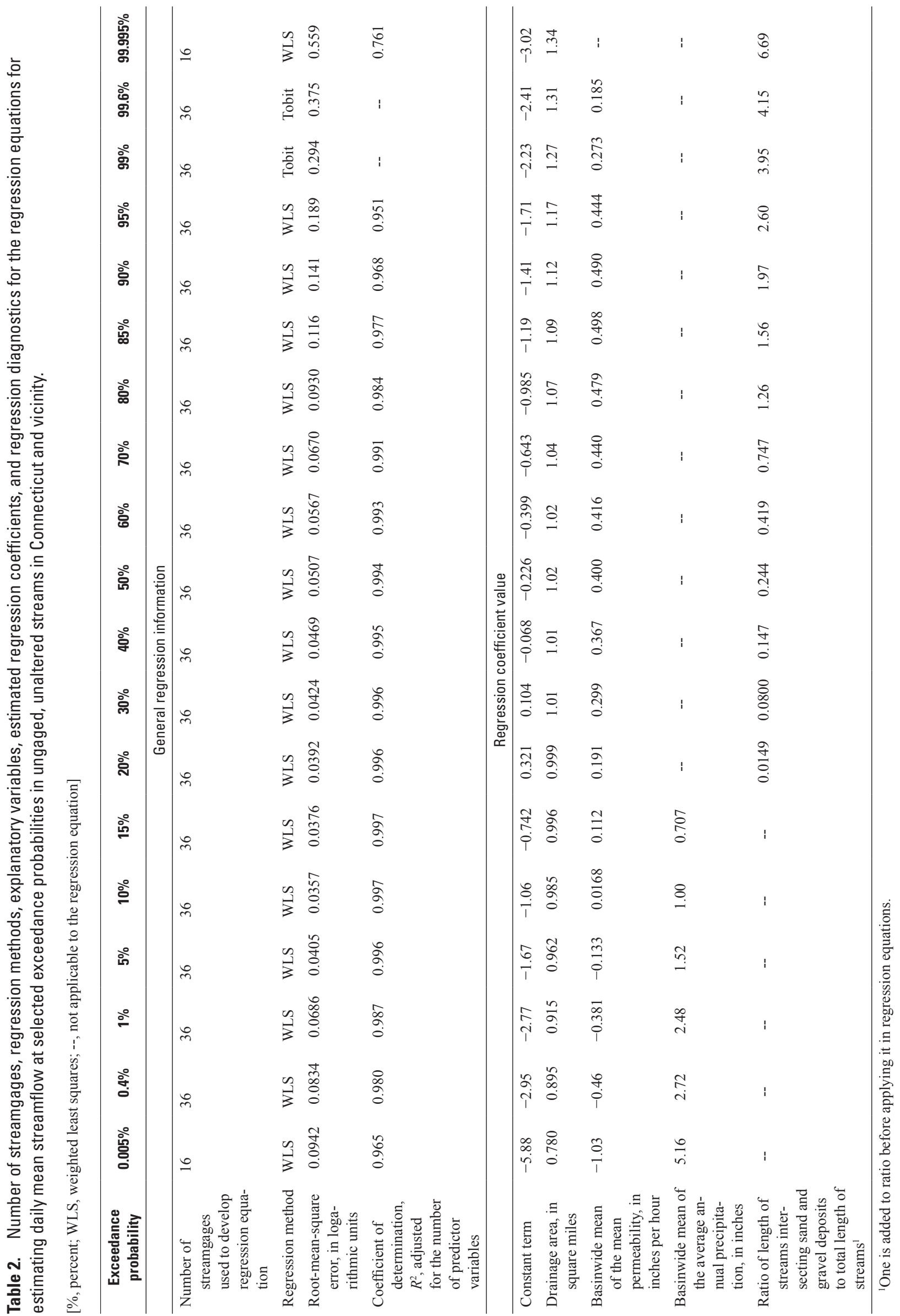


Table 3. Basin characteristics used to develop the regression equations for estimating daily mean streamflow at selected exceedance probabilities for ungaged, unaltered streams in Connecticut and vicinity.

[USGS, U.S. Geological Survey; mi², square mile; RI, Rhode Island; CT, Connecticut; MA, Massachusetts; NY, New York]

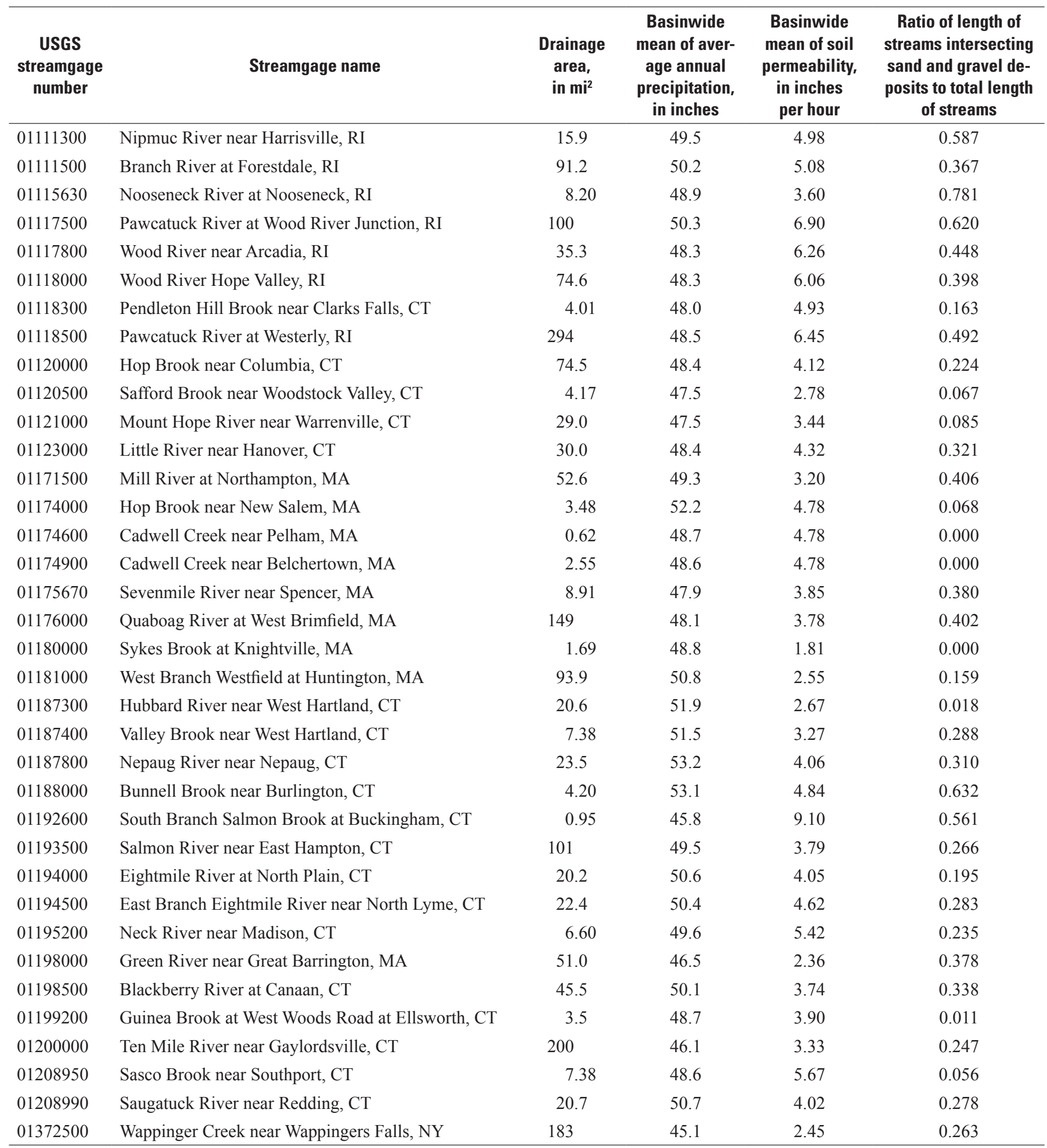


Table 4. Ranges of explanatory variables used in the development of the regression equations for estimating daily mean streamflow at selected exceedance probabilities for ungaged, unaltered streams in Connecticut and vicinity.

\begin{tabular}{lccc}
\hline \multicolumn{1}{c}{ Basin characteristic } & $\begin{array}{c}\text { Mini- } \\
\text { mum }\end{array}$ & Mean & $\begin{array}{c}\text { Maxi- } \\
\text { mum }\end{array}$ \\
\hline $\begin{array}{l}\text { Drainage area, in square miles } \\
\text { Basinwide mean of average annual } \\
\text { precipitation, in inches }\end{array}$ & 0.62 & 49.8 & 294 \\
$\begin{array}{l}\text { Basinwide mean of soil perme- } \\
\text { ability, in inches per hour }\end{array}$ & 1.81 & 49.2 & 53.2 \\
$\begin{array}{l}\text { Ratio of length of streams inter- } \\
\quad \text { secting sand and gravel deposits } \\
\text { to total length of streams }\end{array}$ & 0.000 & 0.286 & 0.10 \\
\hline
\end{tabular}

residuals were generally homoscedastic and normally distributed, and variables in the final equations had varianceinflation factors of less than 1.5 , indicating minimal correlation between the independent variables (Freund and Littell, 2000).

The regression equations are applicable to sites on streams in the study area with minimally developed basins and no upstream flow alteration or water use. Use of the equations is appropriate to sites with basin characteristics that are within the range of basin characteristics used in the development of the equations. The ranges of drainage-basin characteristics used in the analysis are shown in table 4. If independent variables used in the regression equations are outside of these ranges, the accuracy of the predictions is unknown.

\section{Estimation of Streamflow Time Series by Use of a Reference Streamgage}

The CT SSWUE estimates a time series of streamflow at an ungaged basin by using the QPPQ method (Fennessey, 1994; Archfield and others, 2010). The QPPQ method assumes that for each day, the exceedance probability of the streamflow at the ungaged site is equal to the exceedance probability at a selected reference streamgage (fig. 2). The QPPQ method transforms the flow-duration curve at the ungaged site to a time series by equating the date of each streamflow quantile in the flow-duration curve for the ungaged site with the date of the same quantile at a reference streamgage. For example, in figure 2, the QPPQ method assumes the streamflow quantile for the 10-percent exceedance probability at the ungaged site (fig. $2 C$ ) occurs on the same date as the streamflow quantile for the 10-percent exceedance probability at the reference streamgage (figs. $2 A$ and $B$ ). In this way, a date can be assigned to all the streamflow quantiles of the flow-duration curve for the ungaged basin.

\section{Reference Streamgages Included in the Study Area}

A network of 61 streamgages with 55-year daily mean streamflow records (water years 1961 to 2015) are included in the CT SSWUE as potential reference streamgages for the QPPQ process of transforming the flow-duration curve at an ungaged site into a daily time series (fig. 1; appendix 1). Streamgages were selected as reference streamgages according to the following criteria: (1) a minimum of 10 years of record and (2) no or minimum regulation, flow augmentation, or water-supply/industrial withdrawals in the upstream basin. Reference streamgages did not have to be active during the 1960s drought. The network of reference streamgages includes the 36 streamgages used in developing the regression equations and an additional 25 streamgages that meet the criteria for a reference streamgage.

Reference streamgages were selected from available streamgages in Connecticut and adjacent, physiographically similar areas in Massachusetts, Rhode Island, and New York (fig. 1; appendix 1). The reference streamgages are spatially well distributed in and near Connecticut. The streamflow data available for the 61 streamgages ranged from 10 to 103 years and were downloaded from the USGS National Water Information System (NWIS) (https://waterdata.usgs.gov/nwis).

The QPPQ method requires that reference streamgages have daily streamflow records for the 55 -year period (October 1, 1960, to September 30, 2015). The records for 48 of the 61 reference streamgages (appendix 3) were extended by using the maintenance of variance extension, type 3 (MOVE.3), technique (Vogel and Stedinger, 1985) to ensure that all reference streamgages had a period of streamflow record from October 1, 1960, through September 30, 2015. The record extension was done with the Streamflow Record Extension Facilitator, version 1.0, software (Granato, 2009). When extending the record for a streamgage, the streamgage used for extending record was selected on the basis of available record and the best possible correlation of daily mean streamflows. Reference streamgages and streamgages used for record extension are listed in appendix 3.

\section{Selection of a Reference Streamgage for an Ungaged Site}

The performance of the QPPQ method in estimating a daily time series depends upon the similarity between the ungaged site and the chosen reference streamgage. The ideal reference streamgage is the one with the most streamflow values correlated to those at the ungaged site. The CT SSWUE uses the map-correlation method developed by Archfield and Vogel (2010) to select the reference streamgage whose streamflows have the highest predicted correlation to the ungaged basin. The Pearson $r$ correlation coefficient (Helsel and Hirsch, 2002) was computed for the logarithm of daily streamflows between all 61 pairs of reference streamgages 


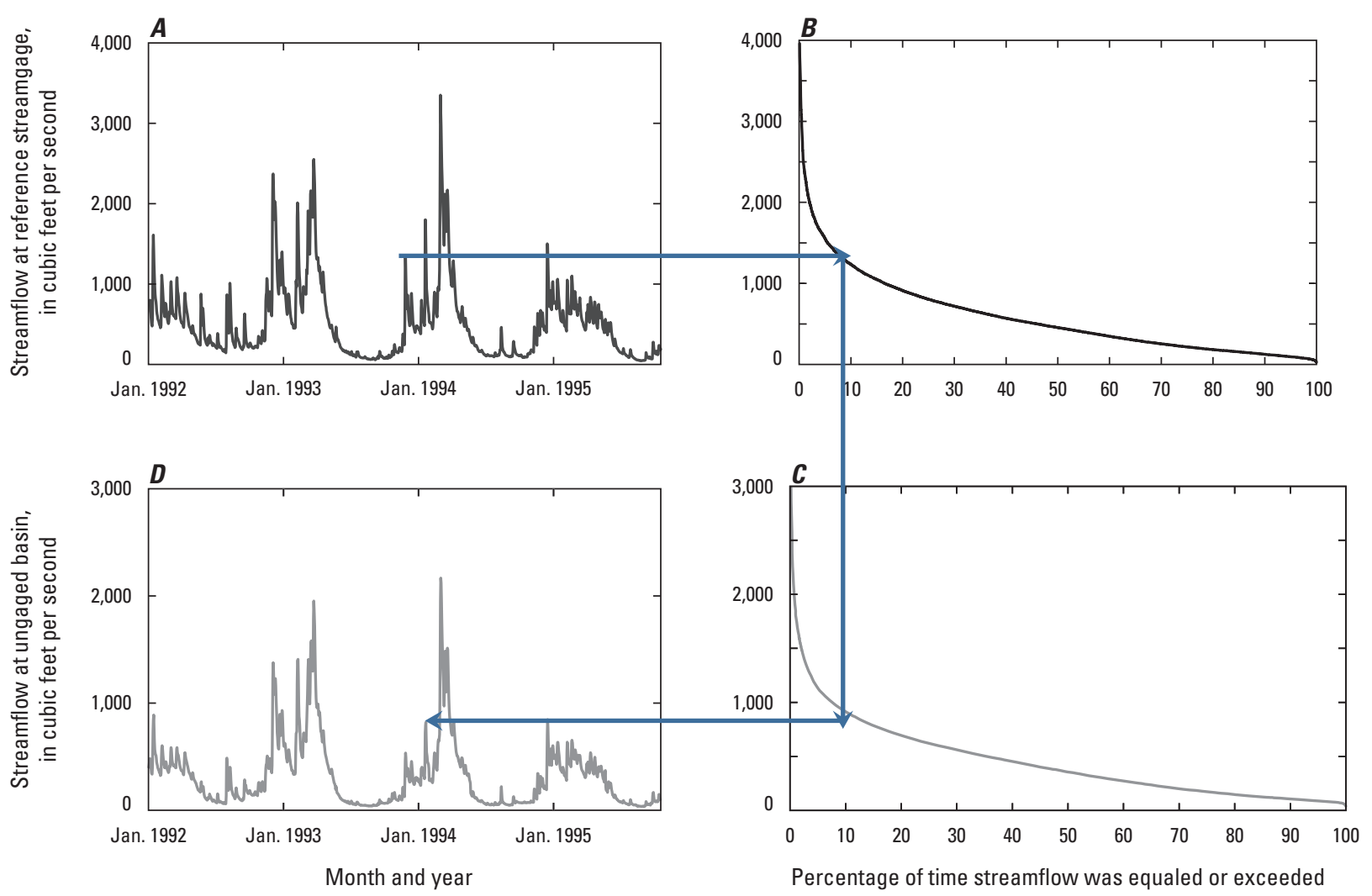

Figure 2. Translation of a flow-duration curve to a time series of streamflow estimated by the Connecticut Streamflow and Sustainable Water Use Estimator using the QPPO method, including $A$, observed time series at a reference streamgage, $B$, flow-duration curve at the reference streamgage, $C$, flow-duration curve for an ungaged basin, and $D$, estimated time series for the ungaged basin. (Modified from Archfield and others, 2010.)

and ungaged sites in the CT SSWUE. The Pearson $r$ values were spatially interpolated through kriging. For each reference streamgage, a spherical variogram model (Isaaks and Srivastava, 1989) was computed that estimated the Pearson $r$ correlation between the reference streamgage and the ungaged site. When running the CT SSWUE for an ungaged basin, the reference streamgage with the highest predicted correlation to the ungaged basin is selected as the reference streamgage to be used for the QPPQ method. Example variogram maps are shown in figure 3. For the variogram of streamgage 01208990, Saugatuck River near Redding, Conn. (fig. $3 A$ ), the areas with the higher estimated correlations are in southwestern Connecticut. For the variogram of streamgage 01194000, Eightmile River at North Plain, Conn., estimated correlations are highest in south-central Connecticut.

\section{Accuracy and Uncertainty of Estimated Unaltered Streamflow}

The accuracy of estimated unaltered, daily mean streamflow time series was assessed at each of the 61 reference streamgages by using a remove-one cross validation. For each reference streamgage, regression equations and the set of variograms used in the reference streamgage selection process were refit to exclude the streamgage from the dataset. Daily mean streamflow at the removed reference streamgage was then estimated from the refit regression and QPPQ process and compared with gaged streamflow at the site. Results from the cross validation represent estimated daily mean streamflows at a basin that was not used in the development of the model.

Estimated daily mean streamflow values agreed overall with observed values. The Nash-Sutcliffe efficiency (NSE) and normalized root-mean-square error (NRMSE) were computed for each of the 61 reference streamgages in the cross validation for the CT SSWUE period of record (water years 19612015), excluding any part of the time series of gaged streamflow for which record-extension techniques were used (fig. 4). NRMSE is calculated as the root-mean-square error divided by the range (maximum minus minimum) of the time series and is expressed as a percentage. NSE values ranged from -0.43 to 0.97 with a median value of 0.88 . NRMSE values ranged from 16.5 to 119.7 percent with a median of 34.6 percent. Figure 5 shows the observed and estimated daily and monthly mean streamflows for the two reference streamgages with the highest and lowest NSE values (01121000, Mount Hope River near Warrenville, Conn., and 01192600, South Branch Salmon Brook at Buckingham, Conn., respectively). Streamgage 


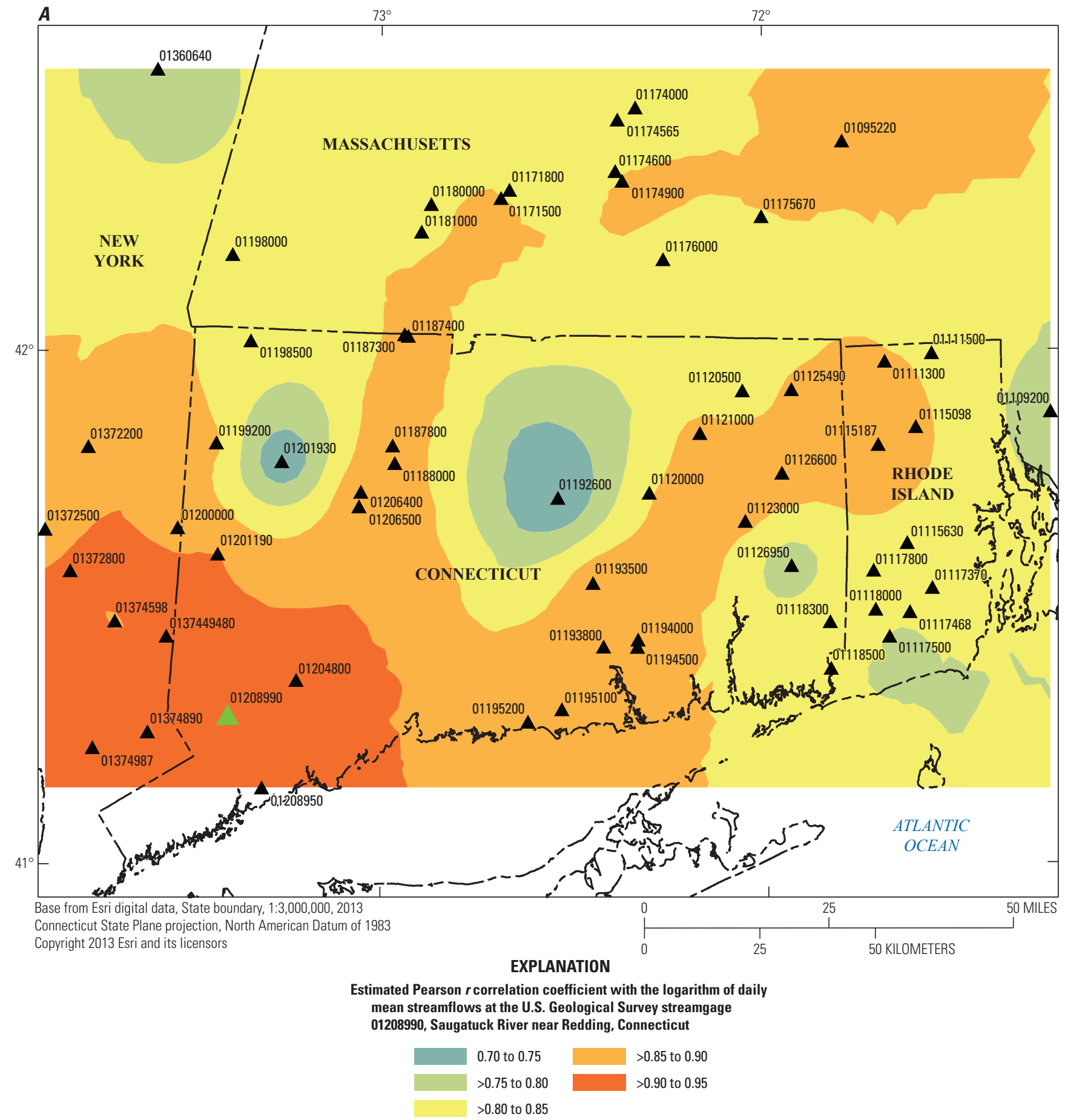

- Streamgage and U.S. Geological Survey streamgage number

Streamgage 01208990, Saugatuck River near Redding, Connecticut

Figure 3. Estimated Pearson $r$ correlation coefficients for streamgages in the study area with the logarithm of daily mean streamflow at the U.S. Geological Survey streamgages $A, 01208990$, Saugatuck River near Redding, Conn., and B, 01194000, Eightmile River at North Plain, Conn., from October 1, 1960, to September 30, 2015. 


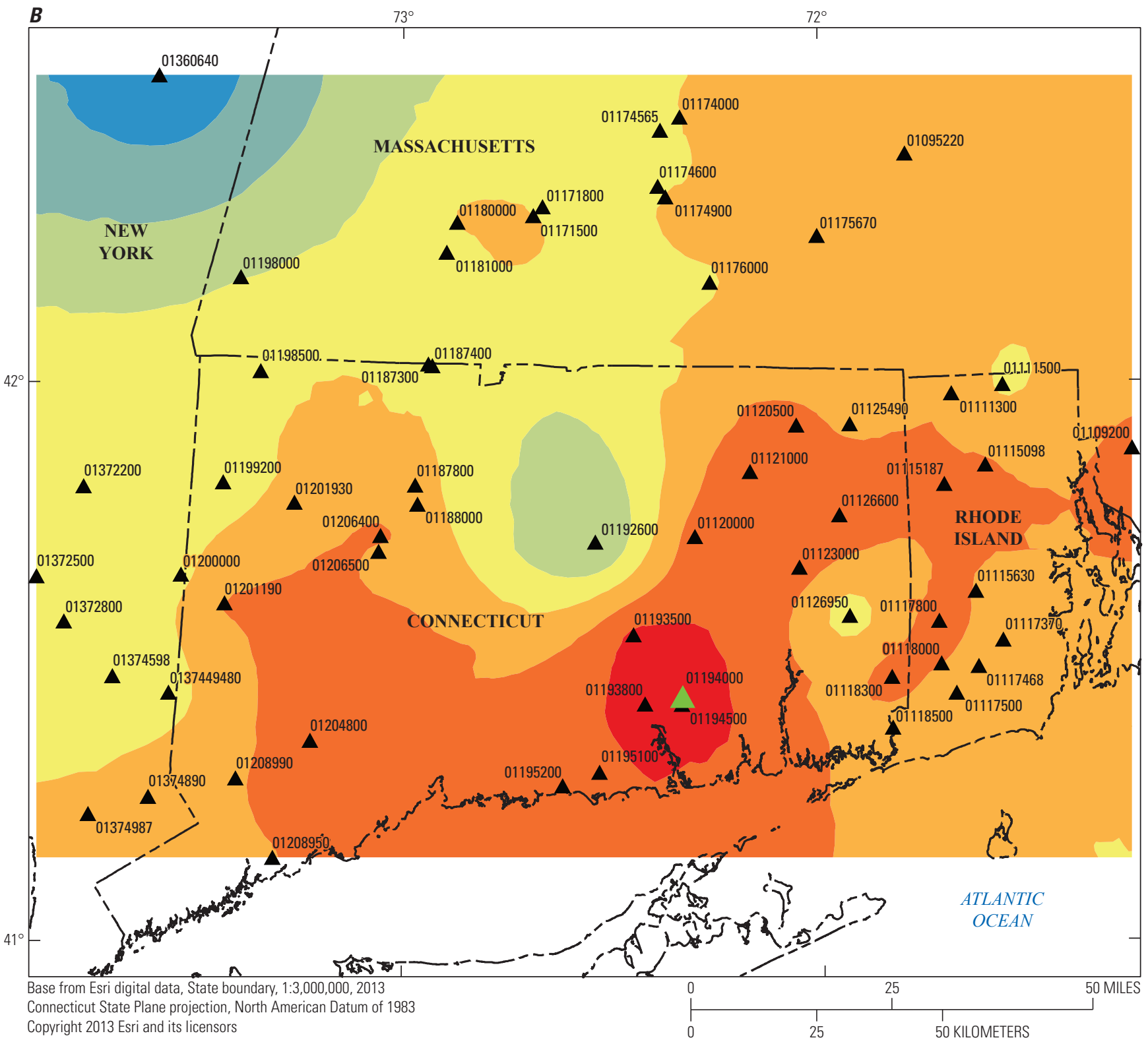

EXPLANATION

Estimated Pearson $r$ correlation coefficient with the logarithm of daily mean streamflows at the U.S. Geological Survey streamgage 01194000, Eightmile River at North Plain, Connecticut

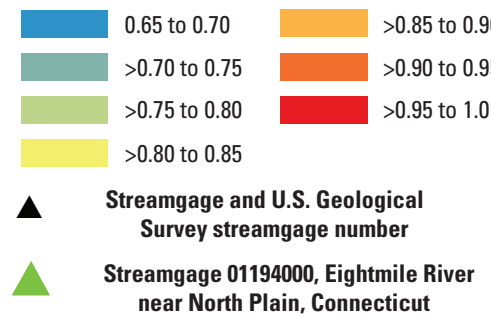

Figure 3. Estimated Pearson $r$ correlation coefficients for streamgages in the study area with the logarithm of daily mean streamflow at the U.S. Geological Survey streamgages A, 01208990, Saugatuck River near Redding, Conn., and B, 01194000, Eightmile River at North Plain, Conn., from October 1, 1960, to September 30, 2015.-Continued 

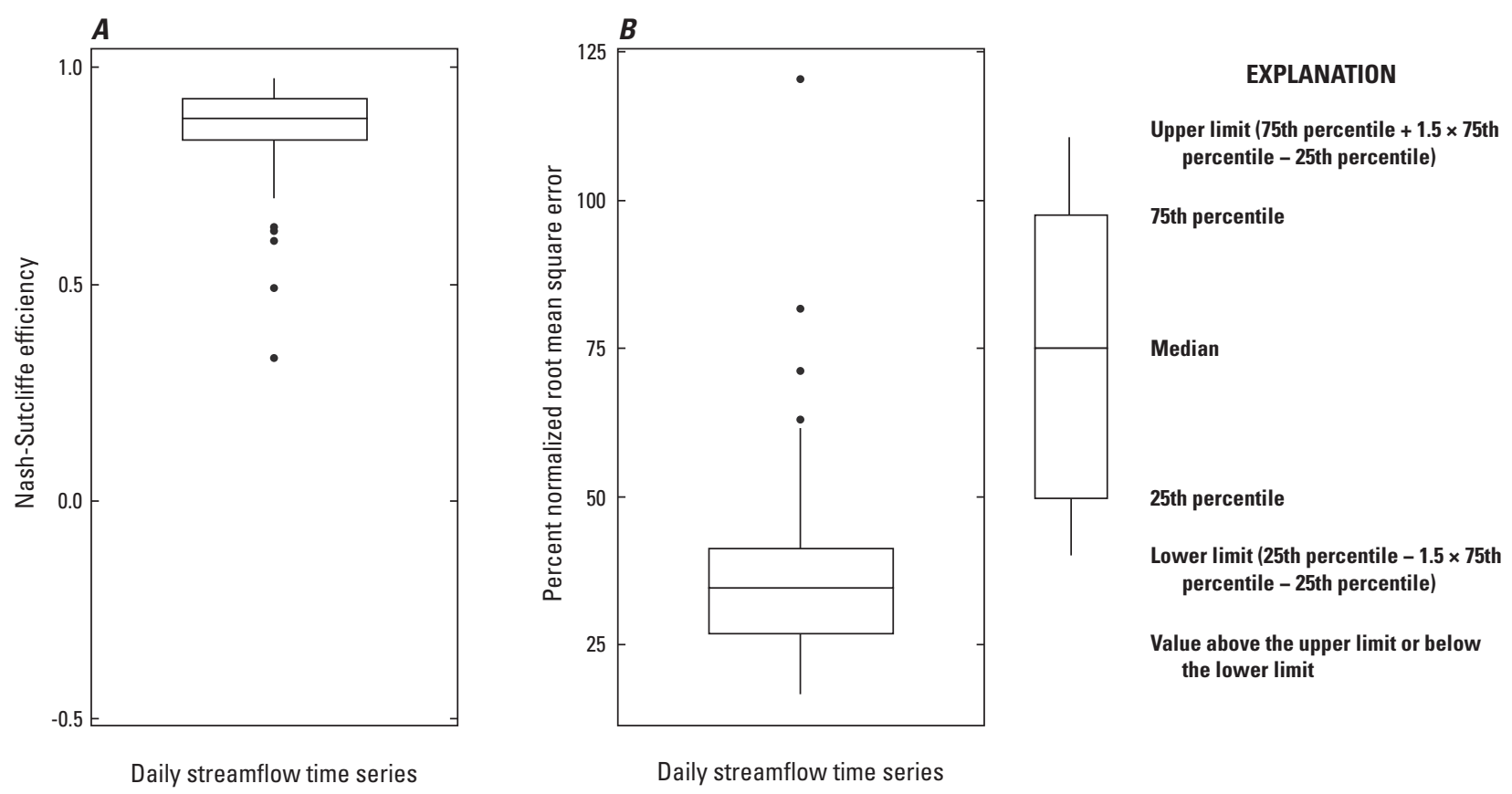

Figure 4. The distributions of $A$, Nash-Sutcliffe efficiency and $B$, normalized root-mean-square error for observed and estimated daily mean streamflow at 61 U.S. Geological Survey streamgages from October 1, 1960, to September 30, 2015, Connecticut and vicinity.

01192600 at South Branch Salmon Brook in Buckingham, Conn. (fig. 1), performed more poorly than other streamgages in the cross validation, with an NSE value of -0.43 and NRMSE of 119.7 percent. Low flows at this site were higher than predicted (fig. 5). The basin for this streamgage has the highest soil permeability of all the reference streamgage sites and is also one of the smallest sites (table 3). Having these basin characteristics at the extreme ends of the ranges may have contributed to high uncertainty in estimated streamflow at this site. Additionally, difficulties associated with measuring low flows in small basins may be a source of increased measurement error in the gaged data at this site.

Daily mean streamflow values are often aggregated for analysis or decision-making purposes. The CT SSWUE summarizes the simulation results as the mean or median for each month, computed as the mean of all the monthly means or median of all the monthly medians for that month over all years of simulation. Figure 6 shows a comparison of the mean of the monthly means for gaged data with the mean of the monthly means for estimated streamflow for all 61 reference streamgages, using the cross-validation data previously described. The mean of the monthly means estimated by the CT SSWUE showed good agreement with the mean for gaged data. The percent errors of the estimated means of the monthly means were unbiased overall and typically ranged between -20 percent and +20 percent. Percent errors were higher in July through October because of lower streamflows during the summer and early fall months.
Uncertainty in the time series of estimated unaltered daily mean streamflow comes primarily from (1) the regression equations and interpolation process used to estimate the continuous flow-duration curve and (2) the reference streamgage selection and QPPQ process used to create the time series of daily mean streamflow. Because uncertainty comes from several different statistical and modeling processes, standard statistical methods for quantifying the uncertainty and confidence intervals of SSWUE-estimated unaltered streamflow are not valid (Archfield and others, 2010). Instead, the CT SSWUE uses a procedure developed by Bourgin and others (2015) and modified by Farmer and Levin (2018) to estimate 95-percent prediction intervals for estimates of daily and monthly average streamflow. The process to construct prediction intervals for daily streamflow estimates at an ungaged site is described below and illustrated in figure 7:

1. Select five reference streamgages $\left(\mathrm{RG}_{n}\right)$ with the highest predicted correlation to the ungaged basin as predicted by the map-correlation method (fig. 7A). Streamflow at these five basins is then estimated with the CT SSWUE as if they were ungaged basins.

2. For each $\mathrm{RG}_{n}$ selected in step 1, select the five reference streamgages $\left(\mathrm{RG}_{n, m}\right)$ that have a predicted correlation to the $\mathrm{RG}_{n}$ that is closest in value to the correlation between the ungaged basin and $\mathrm{RG}_{n}$ (fig. $7 B$ ). 
01192600, South Branch Salmon Brook at Buckingham, Connecticut
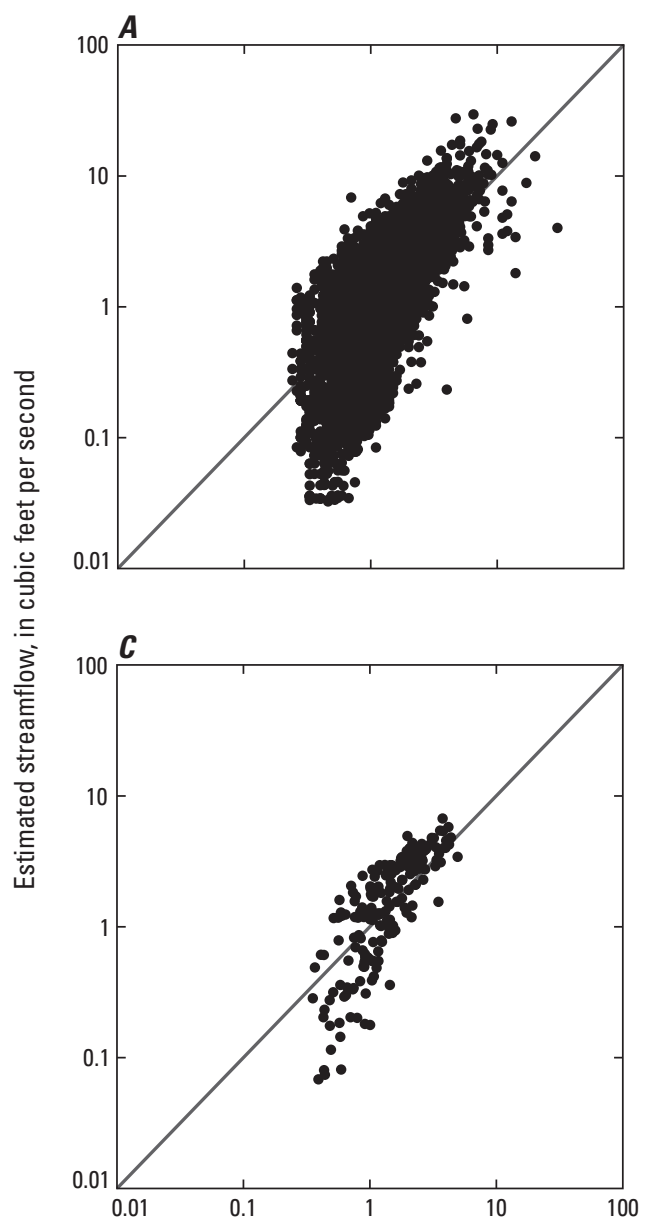

01121000, Mount Hope River near Warrenville, Connecticut

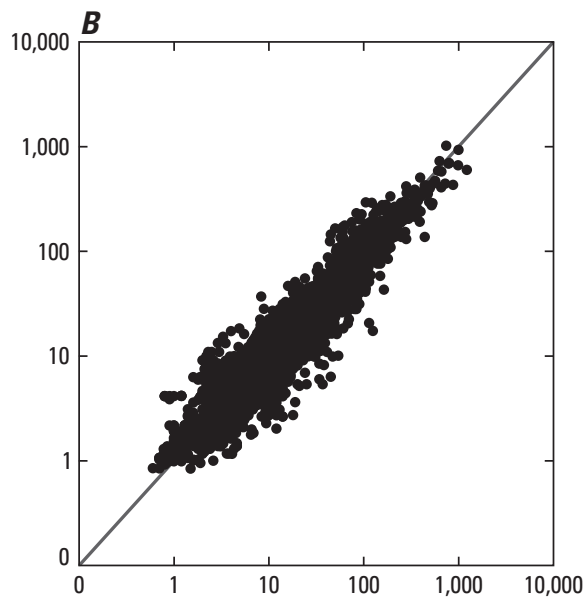

1,000

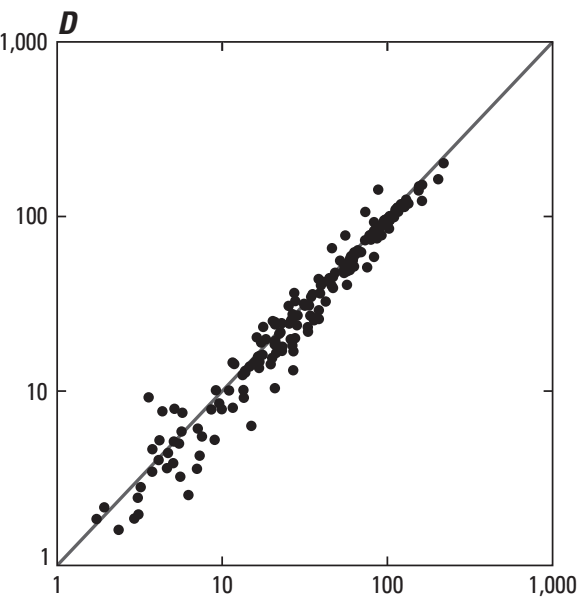

Figure 5. Observed and estimated $A-B$, daily mean streamflow and $C-D$, monthly mean streamflow for U.S. Geological Survey streamgages 01192600, South Branch Salmon Brook at Buckingham, Conn., and 01121000, Mount Hope River near Warrenville, Conn., from October 1, 1960, to September 30, 2015.

3. Use regression equations from a remove-one cross validation to estimate the flow-duration curve at each $\mathrm{RG}_{n}$, and then perform the QPPQ by using each $\mathrm{RG}_{n, m}$ to produce 5 estimated time series of streamflow at each of the $5 \mathrm{RG}_{n}$, for a total of 25 daily time series simulations.

4. For each of the 25 simulated daily time series, compute the error ratio as the observed divided by the estimated streamflow for each day of the period of record, and group the error ratios from all 25 time series by month (fig. 7C).

5. For each month, the error ratios at the 97.5 and 2.5 percentiles (red dots in fig. 7C) are computed from the distribution of error ratios for that month. Upper and lower prediction-interval bounds for each daily streamflow value at the ungaged basin are computed by multiplying simulated streamflow at the ungaged basin by the error ratios at the 97.5 and 2.5 percentiles for the corresponding month.
The prediction interval for a streamflow value on a given day is a range of values that should include the actual streamflow value with an acceptable confidence level. The method used for estimating prediction intervals for a daily mean streamflow value assumes that the prediction errors at sites that are highly correlated to the ungaged site will have a similar distribution at the ungaged site. Prediction intervals for both daily and monthly average streamflow were computed for each reference streamgage in a remove-one cross validation for the CT SSWUE period of record, excluding any periods for which record-extension techniques were used. The performance of the prediction-interval procedure was evaluated by computing the coverage ratio, defined as the percentage of days in the period of record in which the gaged daily streamflow was within the prediction interval. For example, 95-percent prediction intervals should have a coverage ratio of roughly 95 percent at a given site (about 19,070 of 20,075 days in a 55-year record). Coverage ratios ranged from 82.2 percent to 99.9 percent with a median of 96.6 percent 

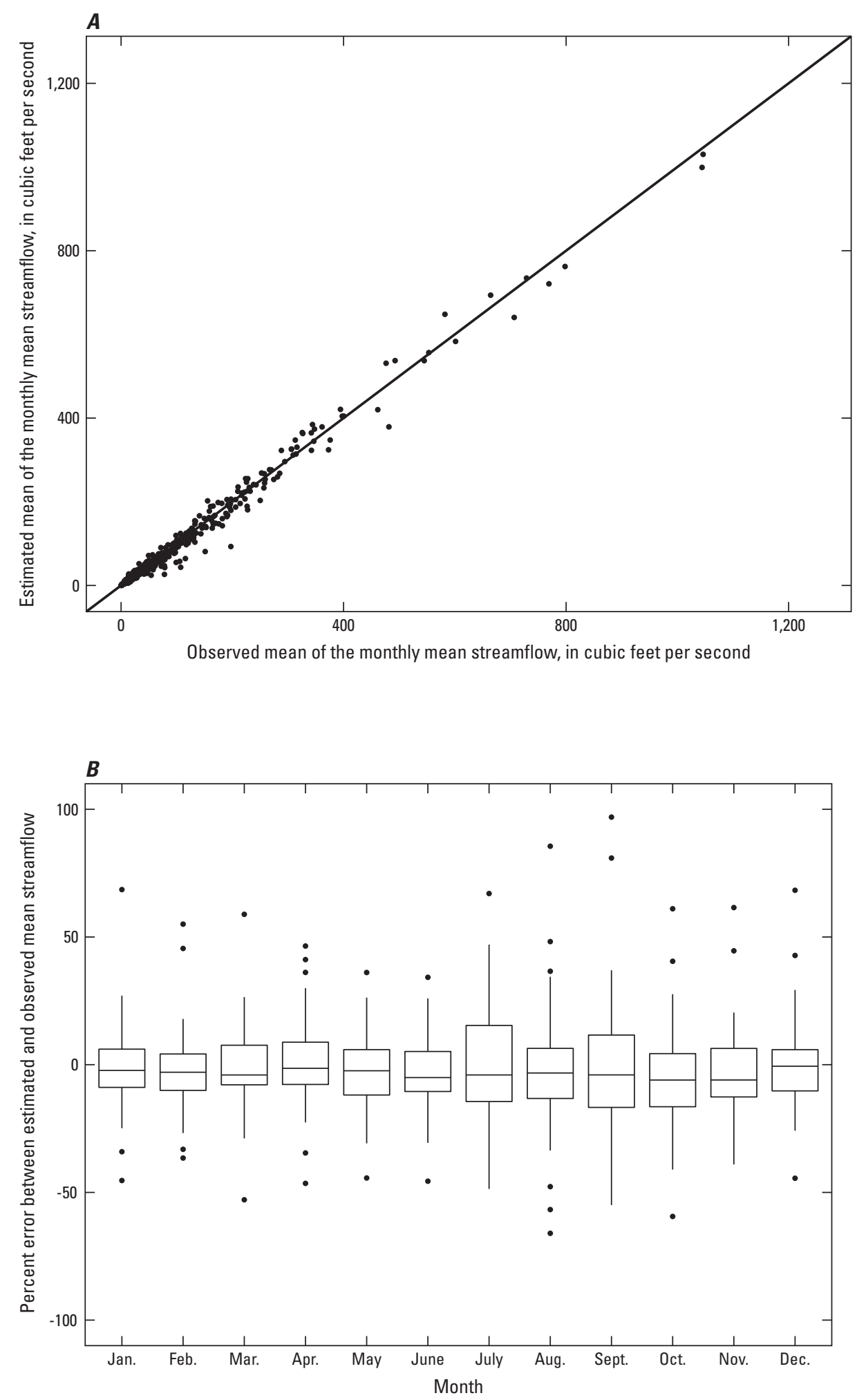

EXPLANATION

Upper limit $(75$ th percentile $+1.5 \times 75$ th percentile -25 th percentile)

75th percentile

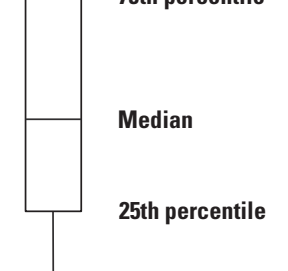

Lower limit (25th percentile $-1.5 \times 75$ th percentile -25 th percentile)

Value above the upper limit or below the lower limit

Figure 6. The observed and estimated mean of the monthly mean streamflow and $B$, the percent error of the estimated mean of the monthly mean streamflow for 61 U.S. Geological Survey streamgages used as reference streamgages in the Connecticut Streamflow and Sustainable Water Use Estimator, from October 1, 1960, to September 30, 2015, Connecticut and vicinity. 

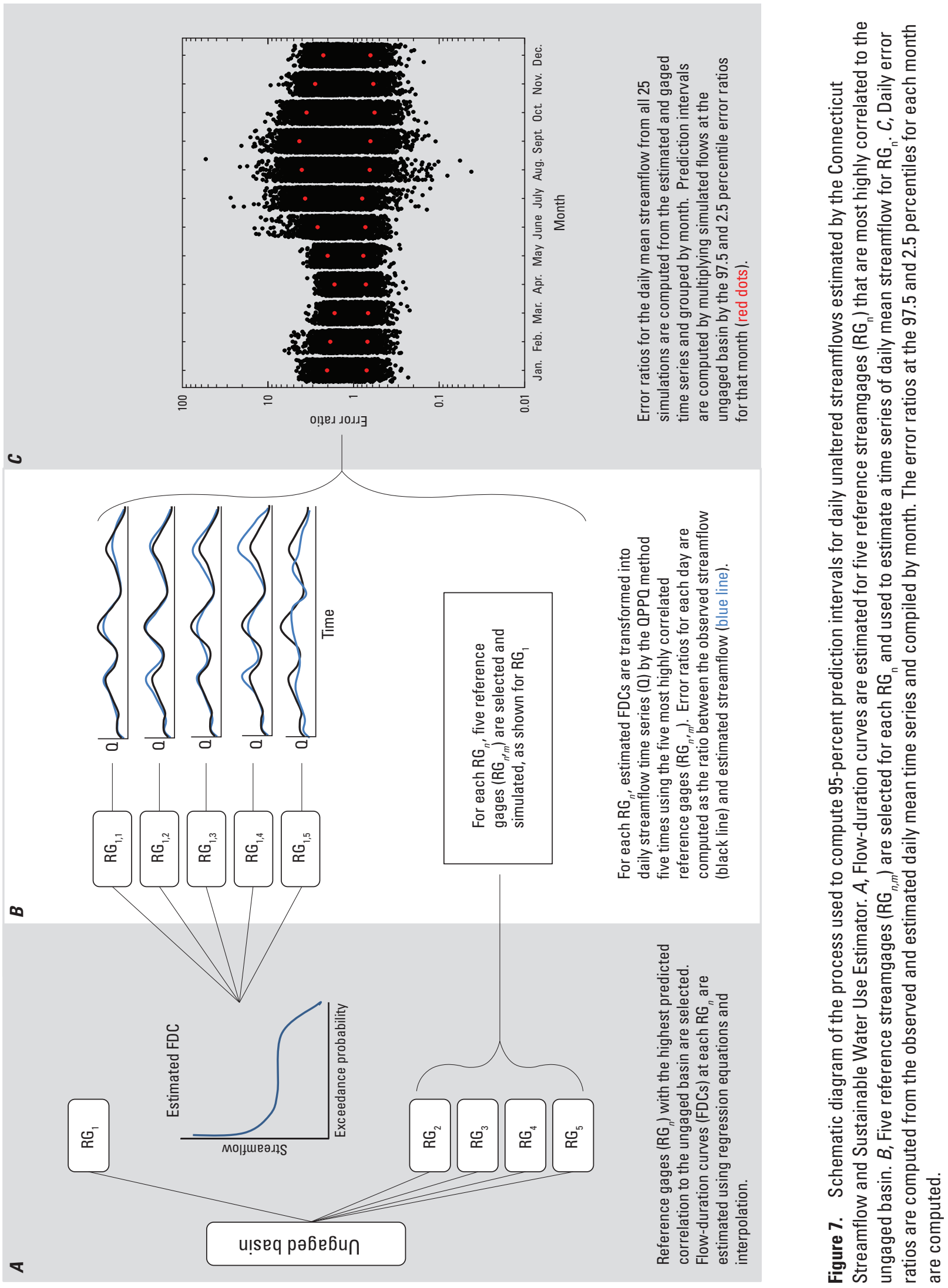
for daily prediction intervals and ranged from 69.8 percent to 100.0 percent with a median of 93.9 percent for monthly streamflows (fig. 8). Prediction intervals performed better for daily time series than monthly time series. This is likely due to the larger sample size of the error ratio distributions used to characterize the 97.5 and 2.5 percentiles in the daily time series. Investigation into the performance and refinement of the prediction-interval procedure is an area of ongoing

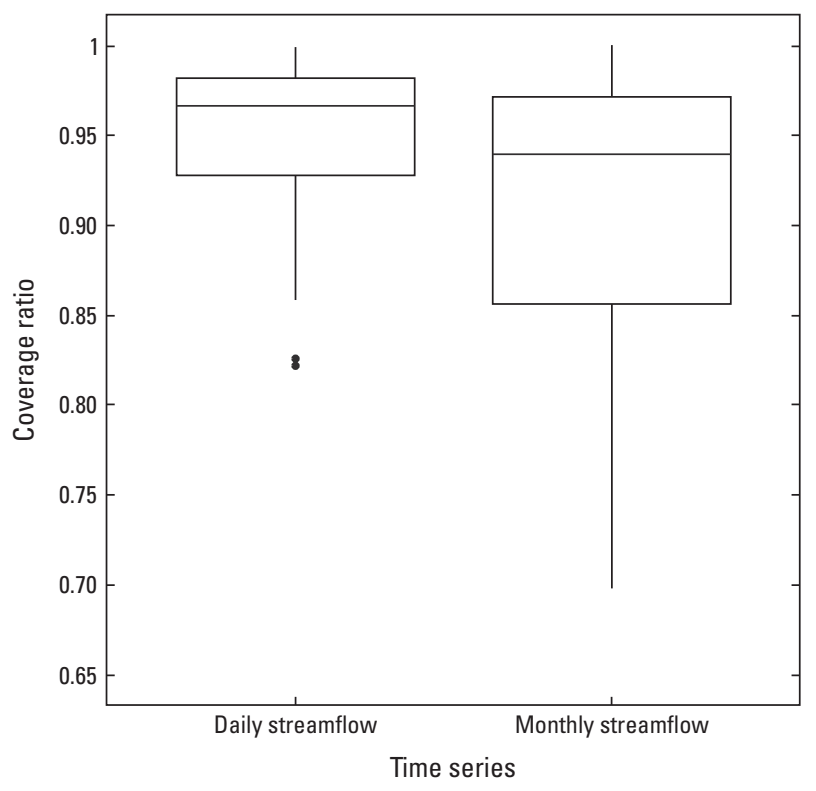

EXPLANATION

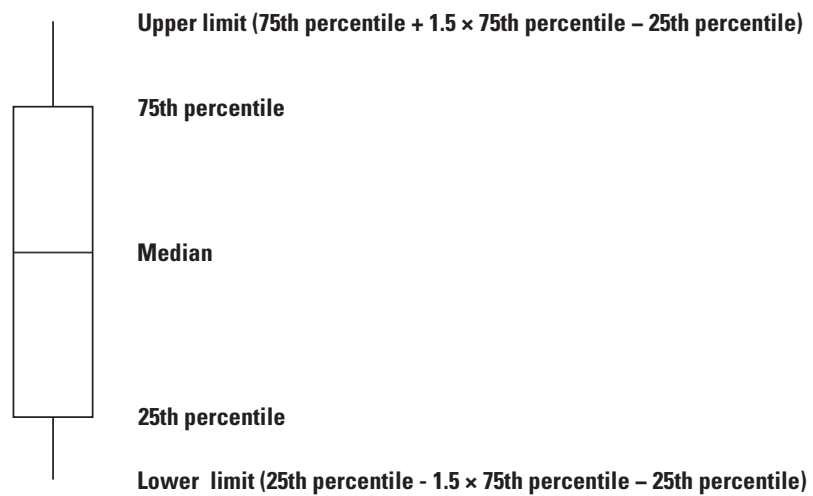

- Value above the upper limit or below the lower limit

Figure 8. The coverage ratio for prediction intervals for daily and monthly mean time series of estimated unaltered streamflow at 61 reference streamgages used in the Connecticut Streamflow and Sustainable Water Use Estimator, from October 1, 1960, to September 30, 2015, Connecticut and vicinity. The coverage ratio is the percentage of days in the period of record in which the gaged daily streamflow was within the prediction interval. research. For the current (2018) CT SSWUE application, the performance at most sites was adequate to provide the user with a reasonable measure of uncertainty in estimated unaltered daily and monthly mean streamflow values.

\section{Estimation of Daily Water-Use- Adjusted Streamflow}

The CT SSWUE computes water-use-adjusted streamflow at a user-defined location on the basis of average monthly water use within the basin. Daily water-use-adjusted streamflow is computed by adding the average daily wastewater discharges and subtracting the average daily water withdrawals of all permitted water-use sources from the estimated unaltered daily mean streamflow:

$$
Q_{A}=Q_{U}+Q_{D}-Q_{W}
$$

where

$$
\begin{gathered}
Q_{A} \quad \begin{array}{c}
\text { is the daily water-use-adjusted streamflow, in } \\
\text { cubic feet per second; }
\end{array} \\
Q_{U} \quad \begin{array}{l}
\text { is the daily unaltered streamflow, in cubic feet } \\
\text { per second; }
\end{array} \\
\begin{array}{l}
\text { is the average daily discharge from all } \\
\text { permitted wastewater discharges within the } \\
\text { basin, in cubic feet per second; and }
\end{array} \\
\begin{array}{l}
\text { is the average daily withdrawal from all } \\
\text { permitted surface-water or groundwater } \\
\text { sources within the basin, in cubic feet per } \\
\text { second. }
\end{array}
\end{gathered}
$$

Average daily water use for each month is applied to the entire 55-year time series of estimated unaltered daily mean streamflow to produce a time series of daily water-useadjusted streamflow. This time series of water-use-adjusted streamflow allows the user to determine if current water use is likely to deplete streamflow to below the user-defined minimum target level under a range of historical hydrologic conditions, including drought periods. Many factors other than water use can affect streamflow, and water-use-adjusted streamflow is not intended to represent actual historical or gaged streamflow in a basin. The water-use-adjusted streamflow time series does not take into account variability in water use from year to year, changes in streamflow due to upstream dams or culverts, or the effects of impervious surface or landuse change within the basin.

\section{Time-Lagged Streamflow Depletion From Ground water Withdrawals}

The timing of streamflow alteration from groundwater withdrawals is affected by many factors, including the distance of the well to the stream and the transmissivity of the aquifer. When groundwater withdrawal volumes vary in time, there 
may be a delay in the timing of the corresponding streamflow alteration. The CT SSWUE estimates the time-lagged streamflow alteration from groundwater withdrawals using algorithms developed for the USGS Hydrologic Drought Decision Support System (HyDroDSS) (Granato, 2014). Monthly groundwater response coefficients range from 0.0 to 1.0 and proportion each monthly water-use volume to the month of pumping and the 11 following months. For example, a response coefficient of 1.0 in the first month of pumping indicates that streamflow depletion in that month is equal to the volume of pumping. A response coefficient of 0.5 in the first month indicates that streamflow depletion in the first month of pumping is only 50 percent of the pumping volume for that month and that the rest of the pumping volume would cause depletions in subsequent months. Groundwater withdrawals cause reductions in evapotranspiration as well as reductions in streamflow, so the total depletions from groundwater withdrawals commonly are one or more percentage points smaller than the withdrawals (Barlow and Dickerman, 2001; DeSimone and others, 2002; Eggleston, 2004; Granato and Barlow, 2005; Bent and others, 2011; Barlow and Leake, 2012). Therefore, the final response-coefficient values for each groundwater site were adjusted so that they sum to 99.5 percent.

Because the effects of pumping may persist for several months after pumping, the streamflow depletion for a given month is equal to the depletions caused by the current month's pumping plus the continuing effects of the previous 11 months of pumping. The total streamflow depletion from a groundwater source for a given month is computed as

$$
Q s=\sum_{k=1}^{12} r_{k} Q w_{k},
$$

where

$$
\begin{gathered}
Q s \quad \begin{array}{c}
\text { is the streamflow depletion from a single } \\
\text { groundwater pumping site for a given } \\
\text { month, }
\end{array} \\
\begin{aligned}
& r_{k} \text { is the response coefficient for the pumping } \\
& \text { site, }
\end{aligned} \\
\begin{array}{c}
\text { is the average pumping rate for month for the } \\
\text { current and prior } 11 \text { months }(k), \text { and }
\end{array} \\
k \quad \begin{array}{l}
\text { is an index for the current month and the } \\
\text { preceding } 11 \text { months of pumping. }
\end{array}
\end{gathered}
$$

Total streamflow depletion for a given month is equal to the sum of depletions from all individual groundwater sources within the basin. Surface water withdrawals are assigned a response coefficient of 1.0, which corresponds to an immediate alteration in streamflow with no persisting effect on streamflow in subsequent months.

Response-coefficient values were compiled from results of calibrated three-dimensional MODFLOW models for 108 groundwater sites documented in 7 USGS modeling studies in Rhode Island and central and eastern Massachusetts (Barlow and Dickerman, 2001; DeSimone and others, 2002; Eggleston, 2004; Granato and Barlow, 2005; Bent and others, 2011; Eggleston and others, 2012; Granato, 2014). The 12-month response-coefficient patterns were selected for each groundwater withdrawal or return flow site on the basis of the distance and diffusivity of each site. Groundwater sites that are close to a stream in high-transmissivity aquifers have a rapid alteredflow response. Sites that are distant from the stream or sites in low-transmissivity aquifers have a slow altered-flow response. The 108 groundwater sites were classified into groups with similar transmissivities and stream distances, and average response coefficients from many wells were used to identify depletion patterns and select monthly response-coefficient values for each group. Default values for aquifer transmissivity were assigned to groundwater well locations in Connecticut on the basis of GIS digital data layers of surficial aquifer information (Connecticut Department of Environmental Protection, 2008). The shortest flow path from each groundwater well location to the nearest water body or stream within the basin was computed from digital elevation data (U.S. Geological Survey, 2017b).

\section{Reported Water Use}

Georeferenced, reported water-use data from registered and permitted withdrawal sources and permitted wastewater discharge sources within the Thames River Basin and central coastal drainage basins (fig. 9) were compiled for use in estimating water-use-adjusted streamflow and sustainable net withdrawal at ungaged sites. Wastewater discharge data were included for 57 sites permitted under the National Pollutant Discharge Elimination System for the year 2015. Water withdrawal data for 345 sites were compiled from CT DEEP databases of permitted and registered water, with reported data spanning various years from 1998 to 2015. The Water Diversion Policy Act, in section 22a-368 of the Connecticut General Statutes, outlines the requirements for registering and permitting individual and general withdrawals (Connecticut Department of Energy and Environmental Protection, n.d.). The sites in these databases were supplemented by additional sites that had withdrawal data from 2006-15 that were reported to the CT DEEP Utilities Regulatory Authority (CT PURA) in the required annual reports for certain water utilities (63 sites) and by public water-supply systems (181 sites) too small to be included in the CT DEEP permitting system. The small public water-supply systems had estimated withdrawal data for the 2015 calendar year (Dieter and Maupin, 2017). Water withdrawals were reported as either annual volumes (disaggregated into constant average daily withdrawals) or monthly average daily withdrawals for each year of data.

For some registered, permitted water withdrawals, no reported data were available. The registered or permitted daily volumes were used as the daily water withdrawal volumes for these sites (91 sites). Of the total registered and permitted sites, 17 were known to be inactive as of 2015, and for these sites the withdrawal values were set to zero.

Three large public water supply systems in the study area are composed of withdrawal sites, diversion tunnels, points 


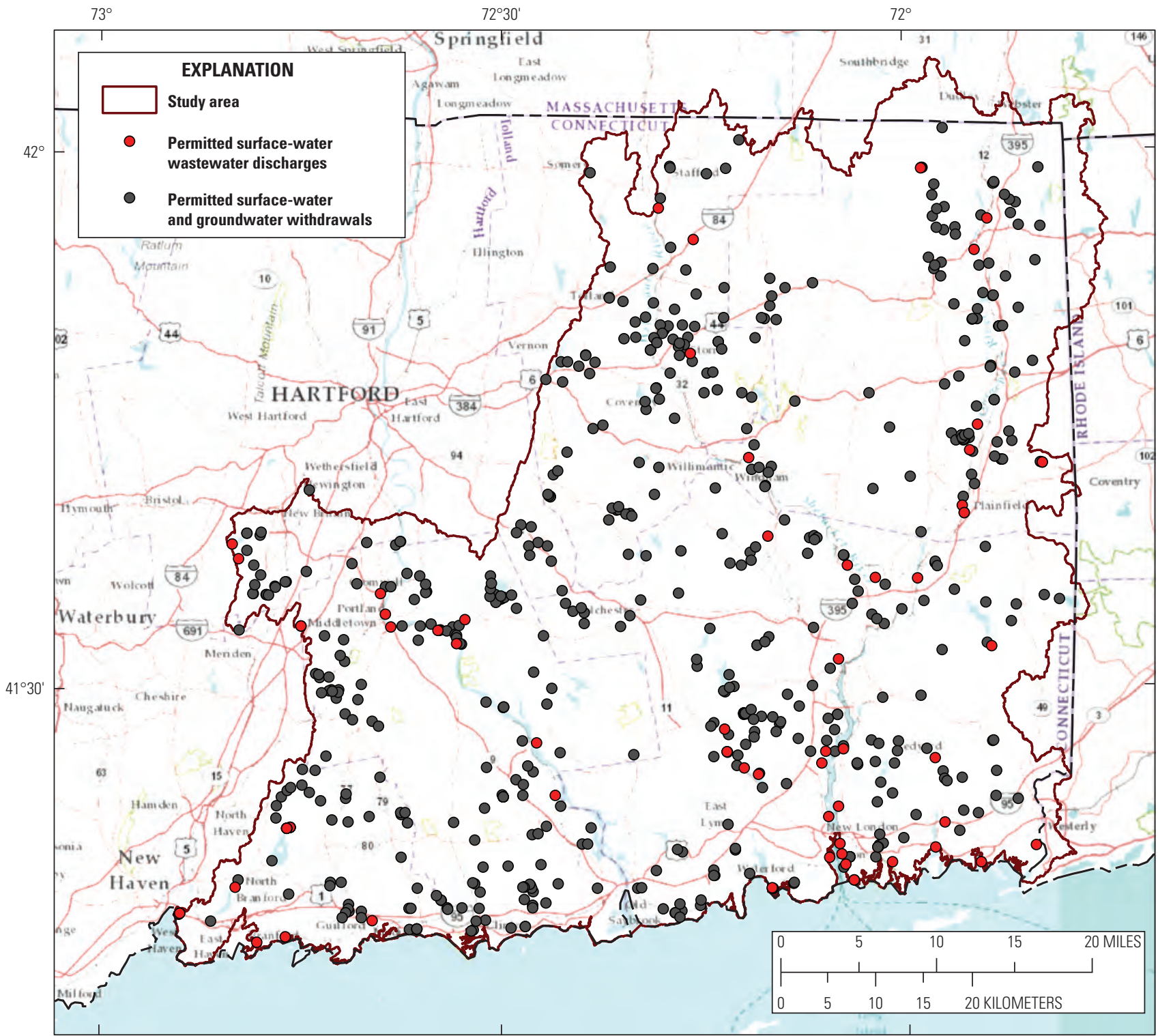

Base from Esri, DeLorme, U.S. Geological Survey, and National Park Service

digital data, Esri State boundary, 1:3,000,000, 2013, and Esri World Reference, 2017

Connecticut State Plane projection, North American Datum of 1983

Copyright 2017 Esri and its licensors

Figure 9. Locations of permitted water withdrawals and wastewater discharges in central and eastern Connecticut used in the Connecticut Streamflow and Sustainable Water Use Estimator.

of tunnel discharge back into other surface-water bodies, and final withdrawal to the public-supply treatment and distribution facilities. The CT SSWUE water-use database includes each of these withdrawal and wastewater discharge volumes.

Reported water-use data were incorporated into the USGS StreamStats web application for Connecticut for use with the CT SSWUE. For a user-defined location, StreamStats provides a summary of average monthly use for all upstream withdrawals and wastewater discharges that were included in the State's database. Water-use information is reported on a basinwide scale, and information regarding the location or water use of a specific source is not available to the user. Data for residential wells and septic discharges were not available at the time of model development and are not included in the StreamStats water-use summaries. Users have the option to alter or update the water-use information for their basin of interest within the CT SSWUE. 


\section{Using the Connecticut Streamflow and Sustainable Water Use Estimator to Estimate Daily Streamflow and Sustainable Net Withdrawal}

The CT SSWUE software was developed in Microsoft Access with a menu-driven GUI, which was designed be used in conjunction with the USGS StreamStats web application. Geoprocessing steps, including basin delineation, computation of basin characteristics, and the compilation of a monthly water-use summary for the ungaged basin, are performed in StreamStats by the user before the CT SSWUE is run. Data exported from StreamStats are accessed by the CT SSWUE, which computes the daily unaltered and water-use-adjusted streamflows and sustainable net withdrawal. The CT SSWUE software and user manual (Granato and Levin, 2018a, b) are available at https://doi.org/10.5066/P9V6ARUS and https://doi.org/10.3133/ofr20181169, respectively.

\section{Limitations}

The use and interpretation of estimated streamflow from the CT SSWUE has several limitations. The regression equations are applicable to sites whose basin characteristics fall within the ranges used for equation development (table 4). If basin characteristics at an ungaged site are outside of these ranges or are computed from different geospatial datasets than those described in the "Streamgage Selection and Basin Characteristics" section, the accuracy of the predicted flowduration curve is unknown. The CT SSWUE is not applicable along the main stem of the Connecticut River (fig. 9) because the size of the drainage area is outside the applicable range for regression equations.

Estimated water-use-adjusted daily streamflows for the 55-year period from October 1, 1960, to September 30, 2015, do not account for changes in streamflow due to upstream dams or culverts, impervious surface, or changes in land use over time. Use of the CT SSWUE in basins with large reservoirs may not adequately reflect the water availability at the location of interest because of regulation and water storage in upstream impoundments.

Water-use information within the USGS StreamStats web application for Connecticut is not available for the entire State and does not include data from some water-use sources. Volumes of withdrawals from private domestic wells, septic discharge, and permitted groundwater discharge were not available for inclusion in the CT SSWUE. Additionally, wateruse information is not available for areas outside of Connecticut. Users of the CT SSWUE may add this information, if known, when running the application if the basin of interest crosses State boundary lines.
Estimates of altered streamflow include uncertainty in the reported water-use volumes and in the method used to estimate time-lagged streamflow depletion from groundwater withdrawals. Water-use data are self-reported with unknown uncertainty and may have variable precision and accuracy. Aquifer properties used for groundwater withdrawal sites were estimated from existing digital data layers that provide ranges of transmissivity for large geographical areas and have unknown uncertainty in their applicability to a specific well location. Groundwater response coefficients for groundwater withdrawal sites were developed by using calibrated groundwater models in Massachusetts and Rhode Island. Although the hydraulic properties of aquifers in Connecticut are similar to those in the calibrated study areas, the applicability of the response coefficients in Connecticut was not tested.

\section{Summary}

Water-resource managers need information regarding water availability and the potential effect of water-use practices on the natural flow regime at ungaged locations. The Connecticut Streamflow and Sustainable Water Use Estimator (CT SSWUE), developed by the U.S. Geological Survey in cooperation with the Connecticut Department of Energy and Environmental Protection, is a statewide decisionsupport tool that estimates water availability under both unaltered and water-use scenarios over a range of historical hydrologic conditions.

The CT SSWUE provides estimates of daily unaltered and water-use-adjusted streamflow for a 55 -year period from October 1, 1960, to September 30, 2015, using a combination of statistical and transfer methods. Weighted least squares and Tobit regression techniques were used to develop equations for estimating 19 streamflow quantiles ranging from 0.005 to 99.995 percent at ungaged sites. The drainage-basin characteristics - drainage area, mean of the soil permeability, mean of the average annual precipitation, and ratio of the length of streams that overlay sand and gravel deposits to the total length of streams in the basin - are used as explanatory variables in the equations. A continuous, daily flow-duration curve for an ungaged site is produced by interpolating the streamflow values among the regression-estimated streamflow quantiles. The flow-duration curve is converted to a daily time series by using the QPPQ method, which assumes that streamflow quantiles at the ungaged site and a reference streamgage site occur on the same day. A network of reference (minimally altered flow) streamgages, which includes the 36 streamgages used in developing the regression equations and an additional 25 streamgages, is used to assign a streamflow quantile to each day of the simulation period. A reference streamgage is identified by using a map-correlation method, which predicts the correlation between streamflows at the ungaged site and the reference streamgage site. 
The accuracy of estimated daily unaltered streamflows was assessed through a remove-one cross validation at each of the 61 reference streamgages. For daily streamflows, NashSutcliffe efficiency ranged from -0.43 to 0.97 with a median value of 0.88 , and the normalized root-mean-square error ranged from 16.6 to 120.4 with a median value of 34.5 percent. Uncertainty in estimates of daily unaltered streamflow arises from multiple sources in the CT SSWUE, including uncertainty associated with the regression equations used to estimate streamflow quantiles, interpolation of the continuous flow-duration curve, and the QPPQ method. Prediction intervals for estimates of unaltered daily and monthly mean streamflows are produced by using an empirical method. Prediction intervals computed for the 61 cross-validation streamgages contained the observed daily streamflow adequately at most sites, with median coverage ratios of 96.6 percent for daily streamflow and 93.9 percent for monthly streamflow.

Water-use-adjusted daily streamflow is computed by the CT SSWUE by adding basinwide average daily wastewater discharges and subtracting water withdrawals. Monthly reported water-use volumes for all permitted surface-water and groundwater withdrawals in the Thames River Basin and central coastal basins for the years 1998 to 2015 were compiled and entered into the U.S. Geological Survey StreamStats web application for Connecticut, which provides summaries of average monthly water use for user-selected ungaged basins. Time-lagged effects of groundwater withdrawals are estimated by using response coefficients developed from published, calibrated three-dimensional groundwater models.

The CT SSWUE computer application was developed in Microsoft Access with a graphical user interface and is designed to be used in conjunction with the Connecticut StreamStats web application. Geoprocessing steps needed for the CT SSWUE, such as basin delineation, compilation of basin characteristics, and basinwide water-use summaries are performed in StreamStats prior to running the CT SSWUE. Data exported from StreamStats are then used in the CT SSWUE application to compute daily streamflow and sustainable net withdrawal. CT SSWUE unaltered and water-use-adjusted streamflows are summarized by month along with user-specified streamflow targets and sustainable net withdrawal estimates for the ungaged basin of interest, and users may export daily and monthly time series of estimated streamflows and prediction intervals.

\section{References Cited}

Abramowitz, M., and Stegun, I.A., eds., 1964, Handbook of mathematical functions with formulas, graphs, and mathematical tables: Washington, D.C., U.S. Department of Commerce, National Bureau of Standards, Applied Mathematics Series, v. 55, 1,046 p.
Ahearn, E.A., 2008, Flow durations, low-flow frequencies, and monthly median flows for selected streams in Connecticut through 2005: U.S. Geological Survey Scientific Investigations Report 2007-5270, 34 p., accessed August 2017 at https://pubs.usgs.gov/sir/2007/5270/.

Ahearn, E.A., 2010, Regional regression equations to estimate flow-duration statistics at ungaged stream sites in Connecticut: U.S. Geological Survey Scientific Investigations Report 2010-5052, 45 p.

Archfield, S.A., Steeves, P.A., Guthrie, J.D., and Ries, K.G., III, 2012, Towards a publicly available, map-based regional software tool to estimate unaltered daily streamflow at ungauged rivers: Geoscientific Model Development, v. 6, p. 101-115. [Also available at http://dx.doi.org/10.5194/ gmd-6-101-2013.]

Archfield, S.A., and Vogel, R.M., 2010, Map correlation method-Selection of a reference streamgage to estimate daily streamflow at ungaged catchments: Water Resources Research, v. 46, no. 10,15 p. [Also available at http://dx.doi.org/10.1029/2009WR008481.]

Archfield, S.A., Vogel, R.M., Steeves, P.A., Brandt, S.L., Weiskel, P.K., and Garabedian, S.P., 2010, The Massachusetts Sustainable-Yield Estimator-A decision-support tool to assess water availability at ungaged stream locations in Massachusetts: U.S. Geological Survey Scientific Investigations Report 2009-5227, 41 p. plus CD-ROM.

Armstrong, D.S., Richards, T.A., and Levin, S.B., 2011, Factors influencing riverine fish assemblages in Massachusetts: U.S. Geological Survey Scientific Investigations Report 2011-5193, 59 p.

Barlow, P.M., and Dickerman, D.C., 2001, Numerical-simulation and conjunctive-management models of the HuntAnnaquatucket-Pettaquamscutt stream-aquifer system, Rhode Island: U.S. Geological Survey Professional Paper 1636, 88 p. [Also available at https://doi.org/10.3133/ pp1636.]

Barlow, P.M., and Leake, S.A., 2012, Streamflow depletion by wells-Understanding and managing the effects of groundwater pumping on streamflow: U.S. Geological Survey Circular 1376, 84 p. [Also available at https://doi.org/10.3133/ cir1376.]

Bent, G.C., Zarriello, P.J., Granato, G.E., Masterson, J.P., Walter, D.A., Waite, A.M., and Church, P.E., 2011, Simulated effects of water withdrawals and land-use changes on streamflows and groundwater levels in the Pawcatuck River Basin, southwestern Rhode Island and southeastern Connecticut: U.S. Geological Survey Scientific Investigations Report 2009-5127, 254 p. [Also available at https://doi.org/10.3133/sir20095127.] 
Bourgin, F., Andréassian, V., Perrin, C., and Oudin, L., 2015, Transferring global uncertainty estimates from gauged to ungauged catchments: Hydrology and Earth System Sciences, v. 19, no. 5, p. 2535-2546. [Also available at https://doi.org/10.5194/hess-19-2535-2015.]

Cadwell, D.H., and others, 1986, Surficial geologic map of New York: New York State Museum Geological Survey Map and Chart Series 40, 1 sheet, scale 1:250,000, accessed March 20, 2017, at http://www.nysm.nysed.gov/ research-collections/geology/gis.

Connecticut Department of Energy and Environmental Protection, n.d., Water diversion program-Background: Connecticut Department of Energy and Environmental Protection web page, accessed May 15, 2017, at http://www.ct.gov/ deep/cwp/view.asp? $\mathrm{a}=2720 \& \mathrm{Q}=404928 \&$ deepNav GID $=1654$.

Connecticut Department of Environmental Protection, 2008, Connecticut surficial aquifer potential: Connecticut Department of Environmental Protection digital data, accessed April 2017 at http://www.ct.gov/deep/cwp/ view.asp?A=2698\&Q=322898.

Connecticut Department of Environmental Protection, 2009, Connecticut surficial stratified drift: Connecticut Department of Environmental Protection digital data, 1:24,000 scale, accessed June 16, 2016, at http://www.ct.gov/deep/ gis.

DeSimone, L.A., Walter, D.A., Eggleston, J.R., and Nimiroski, M.T., 2002, Simulation of ground-water flow and evaluation of water-management alternatives in the Upper Charles River Basin, eastern Massachusetts: U.S. Geological Survey Water-Resources Investigations Report 02-4234, 94 p. [Also available at https://doi.org/10.3133/wri024234.]

Dieter, C.A., and Maupin, M.A., 2017, Public supply and domestic water use in the United States, 2015: U.S. Geological Survey Open-File Report 2017-1131, 6 p., accessed November 2017 at https://doi.org/10.3133/ofr20171131.

Eggleston, J.R., 2004, Evaluation of strategies for balancing water use and streamflow reductions in the Upper Charles River Basin, Eastern Massachusetts: U.S. Geological WaterResources Investigations Report 03-4330, 94 p. [Also available at https://doi.org/10.3133/wri034330.]

Eggleston, J.R., Carlson, C.S., Fairchild, G.M., and Zarriello, P.J., 2012, Simulation of groundwater and surface-water interaction and effects of pumping in a complex glacialsediment aquifer, east central Massachusetts: U.S. Geological Survey Scientific Investigations Report 2012-5172, 48 p., accessed September 2012 at http://pubs.usgs.gov/ $\operatorname{sir} / 2012 / 5172 /$.
Farmer and Levin, 2018, Characterizing uncertainty in daily streamflow estimates at ungauged locations for the Massachusetts Sustainable Yield Estimator: Journal of the American Water Resources Association, v. 54, no. 1, p. 198-210.

Fennessey, N.M., 1994, A hydro-climatological model of daily streamflow for the northeast United States: Medford, Mass., Tufts University, Ph.D. dissertation, variously paged.

Freund, R.J., and Littell, R.C., 2000, SAS system for regression (3d ed.): Cary, N.C., SAS Institute Inc., 236 p.

Gazoorian, C.L., 2015, Estimation of unaltered daily streamflow at ungaged streams of New York, excluding Long Island, water years 1961-2010: U.S. Geological Survey Scientific Investigations Report 2014-5220, 29 p., accessed May 2017, at http://dx.doi.org/10.3133/sir20145220.

Granato, G.E., 2009, Computer programs for obtaining and analyzing daily mean streamflow data from the U.S. Geological Survey National Water Information System Web Site: U.S. Geological Survey Open-File Report 2008-1362, 123 p., accessed March 21, 2017, at https://pubs.usgs.gov/ of/2008/1362/cd_links/WebPart.htm.

Granato, G.E., 2014, Hydrologic Drought Decision Support System (HyDroDSS): U.S. Geological Survey OpenFile Report 2014-1003, 91 p., with CD-ROM, accessed March 2014 at https://pubs.usgs.gov/of/2014/1003/.

Granato, G.E., and Barlow, P.M., 2005, Effects of alternative instream-flow criteria and water-supply demands on ground-water development options in the Big River Area, Rhode Island: U.S. Geological Survey Scientific Investigations Report 2004-5301, 110 p. [Also available at https://doi.org/10.3133/sir20045301.]

Granato, G.E., and Levin, S.B., 2018a, Connecticut Streamflow and Sustainable Water Use Estimator (CTSSWUE) application software: U.S. Geological Survey software release, https://doi.org/10.5066/P9V6ARUS.

Granato, G.E., and Levin, S.B., 2018b, User guide for the Connecticut Streamflow and Sustainable Water Use Estimator (CT SSWUE—version 1.0) computer program: U.S. Geological Survey Open-File Report 2018-1163, 7 p., https://doi.org/10.3133/ofr20181163.

Helsel, D.R., and Hirsch, R.M., 2002, Statistical methods in water resources: U.S. Geological Survey Techniques of Water-Resources Investigations, book 4, chapter A3, 522 p.

Hughes, D.A., and Smakhtin, V.U., 1996, Daily flow time series patching or extension-A spatial interpolation approach based on flow duration curves: Journal of Hydrological Sciences, v. 41, no. 6, p. 851-871.

Isaaks, E.H., and Srivastava, R.M., 1989, An introduction to applied geostatistics: New York, Oxford University Press, $561 \mathrm{p}$. 
Linhart, S.M., Nania, J.F., Christiansen, D.E., Hutchinson, K.J., Sanders, C.L., Jr., and Archfield, S.A., 2013, Comparison between two statistically based methods, and two physically based models developed to compute daily mean streamflow at ungaged locations in the Cedar River Basin, Iowa: U.S. Geological Survey Scientific Investigations Report 2013-5111, 7 p., accessed August 2017 at http://pubs.usgs.gov/sir/2013/5111/.

Lorenz, D.L., and Ziegeweid, J.R., 2016, Methods to estimate historical daily streamflow for ungaged stream locations in Minnesota: U.S. Geological Survey Scientific Investigations Report 2015-5181, 18 p., accessed May, 2017, at http://dx.doi.org/10.3133/sir20155181.

Mahamoud, Y.M., 2008, Prediction of daily flow duration curves and streamflow for ungauged catchments using regional flow duration curves: Hydrological Sciences Journal, v. 53, no. 4, p. 706-724.

Poff, N.L., and Zimmerman, J.K.H, 2010, Ecological responses to altered flow regimes-A literature review to inform the science and management of environmental flows: Freshwater Biology, v. 55, no. 1, p. 194-205.

PRISM Climate Group, 2012, United States average monthly or annual maximum temperature, 1981-2010, $4 \mathrm{~km}$ grid cell resolution, created July 10, 2012: Oregon State University digital data, accessed March 20, 2017, at http://www.prism.oregonstate.edu/.

Rhode Island Geographic Information System, 1989, Rhode Island glacial deposits, s44gg188: Rhode Island Geographic Information System Data Distribution System digital data, accessed March 20, 2017, at http://www.rigis.org/datasets/ glacial-deposits.

SAS Institute Inc., 2009, SAS/STAT(R) 9.2 User's guide (2d ed.): Cary, N.C., SAS Institute Inc., accessed March 14, 2017, at https://support.sas.com/en/support-home.html.

Shu, C., and Ouarda, T.B.M.J., 2012, Improved methods for daily streamflow estimates at ungauged sites: Water Resources Research, v. 48, no. 2, W02523, 15 p.

Smakhtin, V.U., 1999, Generation of natural daily flow time series in regulated rivers using a non-linear spatial interpolation technique: Regulated Rivers: Research and Management, v. 15 , no. 4, p. 311-323.

Smakhtin, V.U., and Masse, B., 2000, Continuous daily hydrograph simulation using duration curves of a precipitation index: Hydrological Processes, v. 14, no. 6, p. 1083-1100.

Stuckey, M.H., 2016, Estimation of daily mean streamflow for ungaged stream locations in the Delaware River Basin, water years 1960-2010: U.S. Geological Survey Scientific Investigations Report 2015-5157, 42 p., accessed May 2017 at https://pubs.er.usgs.gov/publication/sir20155157.
Stuckey, M.H., Koerkle, E.H., and Ulrich, J.E., 2012, Estimation of baseline daily mean streamflows for ungaged locations on Pennsylvania streams, water years 1960-2008: U.S. Geological Survey Scientific Investigations Report 2012-5142, 61 p., accessed May 2017 at https:/pubs.usgs.gov/sir/2012/5142/.

U.S. Geological Survey, 1995, Soils data for the conterminous United States derived from the NRCS State soil geographic (STATSGO) data base (1.1 ed.): U.S. Geological Survey Open-File Report 95-449, accessed March 20, 2017, at https://water.usgs.gov/GIS/metadata/usgswrd/XML/ ussoils.xml.

U.S. Geological Survey, 1999, MassGIS data-Surficial geology (1:250,000): Massachusetts Office of Geographic Information digital data, accessed March 20, 2017, at http://www.mass.gov/anf/research-and-tech/it-serv-andsupport/application-serv/office-of-geographic-informationmassgis/datalayers/sg.html.

U.S. Geological Survey, 2012, The StreamStats programConnecticut: U.S. Geological Survey web page, accessed October 11, 2017, at https://water.usgs.gov/osw/streamstats/ connecticut.html.

U.S. Geological Survey, 2015, MassGIS data-Surficial geology (1:24,000): Massachusetts Office of Geographic Information digital data, accessed March 20, 2017, at http://www.mass.gov/itd/sg24k.

U.S. Geological Survey, 2017a, National hydrography dataset, high resolution: U.S. Geological Survey database, accessed March 20, 2017, at https://nhd.usgs.gov/.

U.S. Geological Survey, 2017b, National StreamStats program: U.S. Geological Survey web page, accessed March 17, 2017, at https://water.usgs.gov/osw/streamstats/.

Vogel, R.M., and Fennessey, N.M., 1994, Flow-duration curves. I-New interpretation and confidence intervals: Journal of Water Resources Planning and Management, v. 120 , no. 4 , p. $485-504$.

Vogel, R.M., and Stedinger, J.R., 1985, Minimum variance streamflow record augmentation procedures: Water Resources Research, v. 21, no. 5, p. 715-723.

Weiss, L.A., 1991, Connecticut floods and droughts, in Paulson, R.W., Chase, E.B., Roberts, R.S., and Moody, D.W., comps., National water summary 1988-89-Hydrologic events and floods and droughts: U.S. Geological Survey Water-Supply Paper 2375, p. 215-222. 
Appendix 1. Reference Streamgages and Periods of Record Used for the Connecticut Streamflow and Sustainable Water Use Estimator

Appendix 2. Basin Characteristics Tested for Use in the Regression Equations for Estimating Streamflow at Ungaged Sites With the Connecticut Streamflow and Sustainable Water Use Estimator

Appendix 3. Dates of Station Record and Dates of Extended Record for Reference Streamgages Used by the Connecticut Streamflow and Sustainable Water Use Estimator 
Table 1.1. Reference streamgages and periods of record used for the Connecticut Streamflow and Sustainable Water Use Estimator.

[All streamgages are shown in figure 1. USGS, U.S. Geological Survey; $\mathrm{mi}^{2}$, square mile; MA, Massachusetts; RI, Rhode Island; CT, Connecticut; NY, New York]

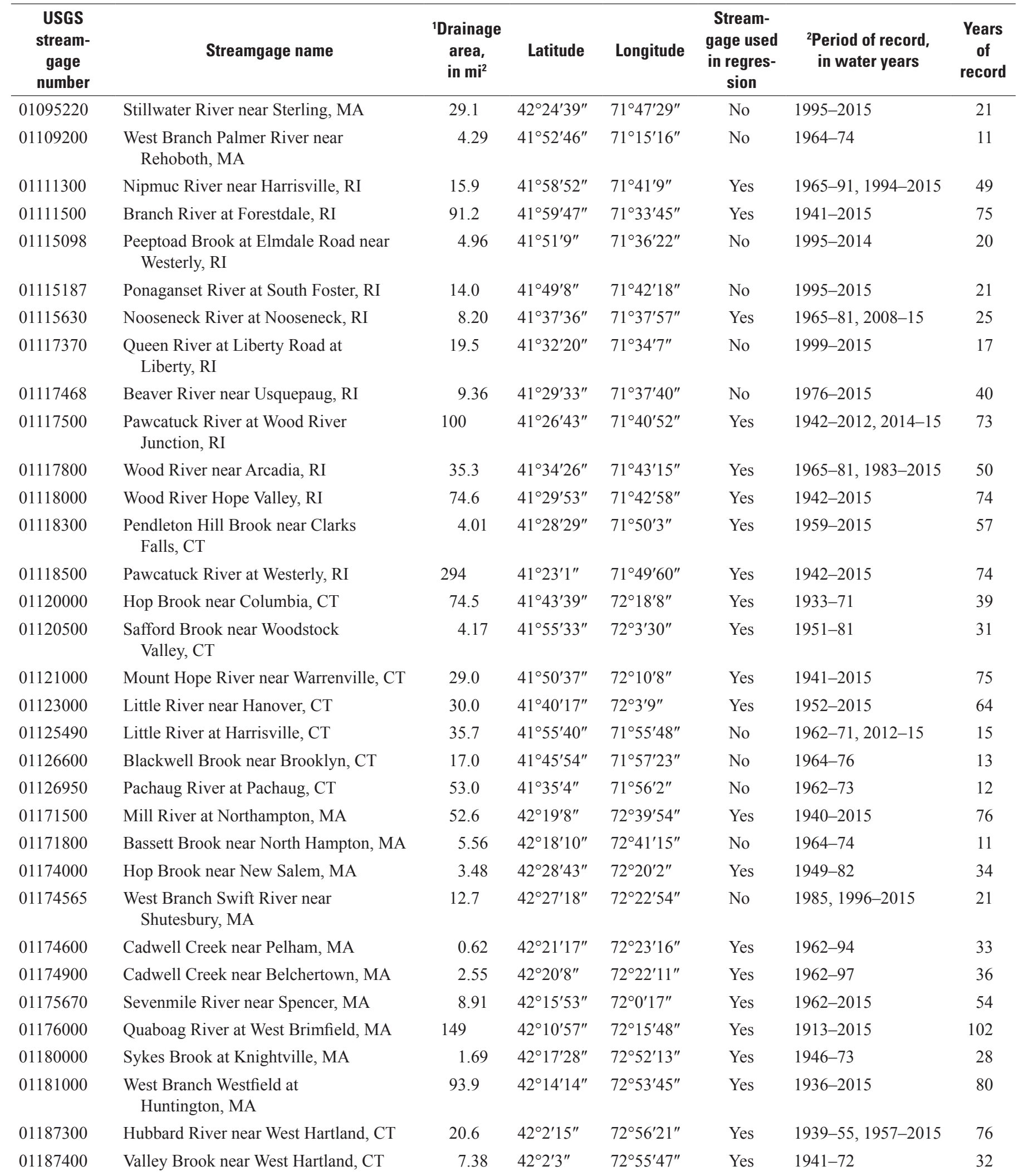


Table 1.1. Reference streamgages and periods of record used for the Connecticut Streamflow and Sustainable Water Use Estimator. -Continued

[All streamgages are shown in figure 1. USGS, U.S. Geological Survey; $\mathrm{mi}^{2}$, square mile; MA, Massachusetts; RI, Rhode Island; CT, Connecticut; NY, New York]

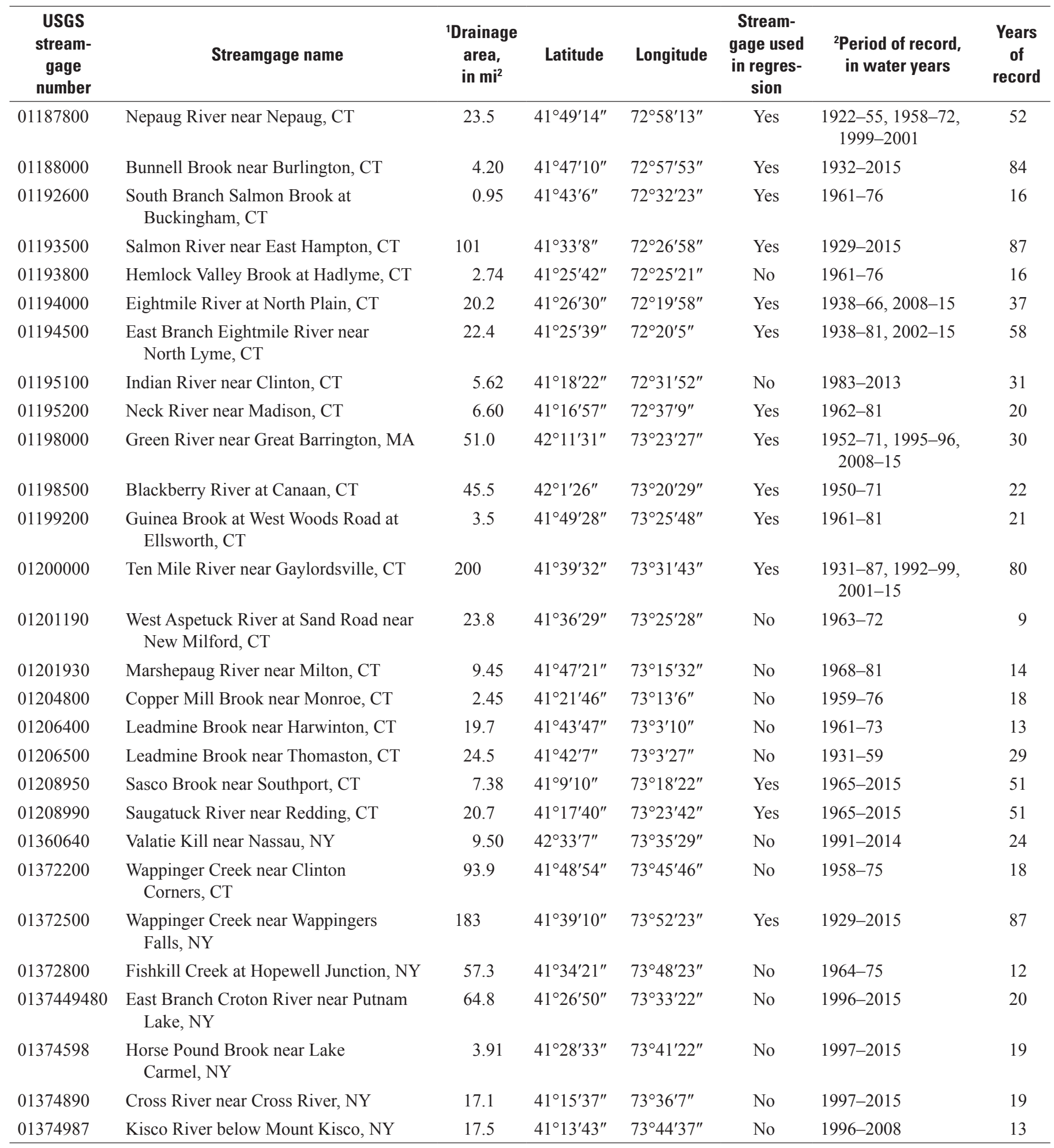

${ }^{1}$ Drainage area determined from a geographical information system and digital datasets and may not match previously published drainage area.

${ }^{2}$ Period of record includes all years with complete daily streamflow record. 
Table 2.1. Basin characteristics tested for use in the regression equations for estimating streamflow at ungaged sites with the Connecticut Streamflow and Sustainable Water Use Estimator.

[ft, foot; ${ }^{\circ} \mathrm{C}$, degrees Celsius; NED, National Elevation Dataset; WBD, Watershed Boundary Dataset; NHD, National Hydrography Dataset; NLCD, National Land Cover Database; PRISM, PRISM Climate Group; NWI, National Wetlands Inventory; gSSURGO, Gridded Soil Survey Geographic; STATSGO, State Soil Geographic; --, no data]

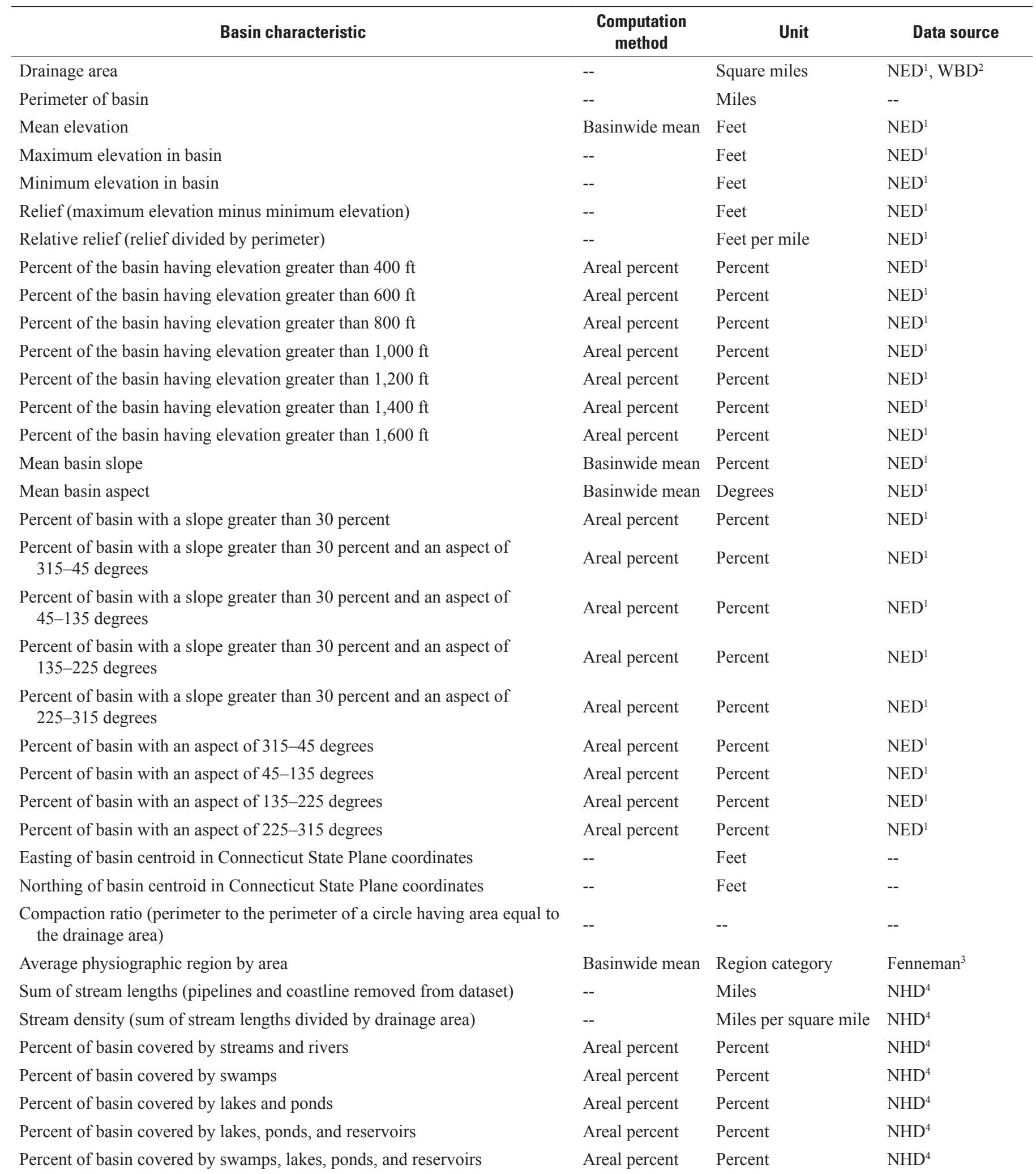


Table 2.1. Basin characteristics tested for use in the regression equations for estimating streamflow at ungaged sites with the Connecticut Streamflow and Sustainable Water Use Estimator.-Continued

[ft, foot; ${ }^{\circ} \mathrm{C}$, degrees Celsius; NED, National Elevation Dataset; WBD, Watershed Boundary Dataset; NHD, National Hydrography Dataset; NLCD, National Land Cover Database; PRISM, PRISM Climate Group; NWI, National Wetlands Inventory; gSSURGO, Gridded Soil Survey Geographic; STATSGO, State Soil Geographic; --, no data]

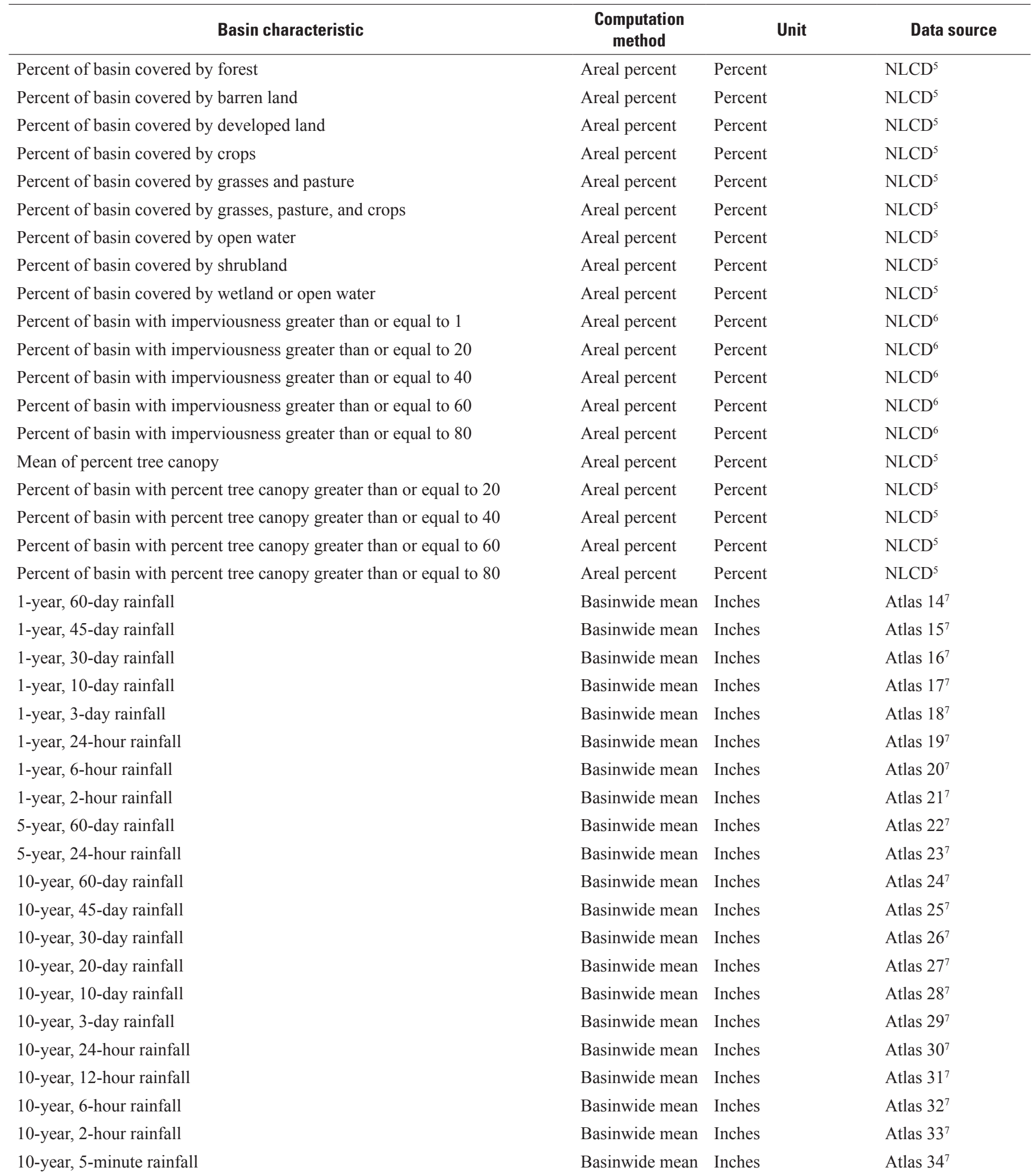


Table 2.1. Basin characteristics tested for use in the regression equations for estimating streamflow at ungaged sites with the Connecticut Streamflow and Sustainable Water Use Estimator.-Continued

[ft, foot; ${ }^{\circ} \mathrm{C}$, degrees Celsius; NED, National Elevation Dataset; WBD, Watershed Boundary Dataset; NHD, National Hydrography Dataset; NLCD, National Land Cover Database; PRISM, PRISM Climate Group; NWI, National Wetlands Inventory; gSSURGO, Gridded Soil Survey Geographic; STATSGO, State Soil Geographic; --, no data]

\begin{tabular}{|c|c|c|c|}
\hline Basin characteristic & $\begin{array}{c}\text { Computation } \\
\text { method }\end{array}$ & Unit & Data source \\
\hline 25-year, 45-day rainfall & Basinwide mean & Inches & Atlas $35^{7}$ \\
\hline Average annual precipitation, $1981-2010$ & Basinwide mean & Inches & PRISM $^{8}$ \\
\hline Average January precipitation, 1981-2010 & Basinwide mean & Inches & PRISM $^{8}$ \\
\hline Average February precipitation, 1981-2010 & Basinwide mean & Inches & PRISM $^{8}$ \\
\hline Average March precipitation, 1981-2010 & Basinwide mean & Inches & PRISM $^{8}$ \\
\hline Average April precipitation, 1981-2010 & Basinwide mean & Inches & PRISM $^{8}$ \\
\hline Average May precipitation, 1981-2010 & Basinwide mean & Inches & PRISM $^{8}$ \\
\hline Average June precipitation, 1981-2010 & Basinwide mean & Inches & PRISM $^{8}$ \\
\hline Average July precipitation, 1981-2010 & Basinwide mean & Inches & PRISM $^{8}$ \\
\hline Average August precipitation, 1981-2010 & Basinwide mean & Inches & PRISM $^{8}$ \\
\hline Average September precipitation, 1981-2010 & Basinwide mean & Inches & PRISM $^{8}$ \\
\hline Average October precipitation, 1981-2010 & Basinwide mean & Inches & PRISM $^{8}$ \\
\hline Average November precipitation, 1981-2010 & Basinwide mean & Inches & PRISM $^{8}$ \\
\hline Average December precipitation, 1981-2010 & Basinwide mean & Inches & PRISM $^{8}$ \\
\hline Average annual maximum daily temperature, $1981-2010$ & Basinwide mean & ${ }^{\circ} \mathrm{C}$ & PRISM $^{8}$ \\
\hline Average annual mean daily temperature, $1981-2010$ & Basinwide mean & ${ }^{\circ} \mathrm{C}$ & PRISM $^{8}$ \\
\hline Average annual minimum daily temperature, $1981-2010$ & Basinwide mean & ${ }^{\circ} \mathrm{C}$ & PRISM $^{8}$ \\
\hline Average mean January temperature, 1981-2010 & Basinwide mean & ${ }^{\circ} \mathrm{C}$ & PRISM $^{8}$ \\
\hline Average mean February temperature, 1981-2010 & Basinwide mean & ${ }^{\circ} \mathrm{C}$ & PRISM $^{8}$ \\
\hline Average mean March temperature, 1981-2010 & Basinwide mean & ${ }^{\circ} \mathrm{C}$ & PRISM $^{8}$ \\
\hline Average mean April temperature, 1981-2010 & Basinwide mean & ${ }^{\circ} \mathrm{C}$ & PRISM $^{8}$ \\
\hline Average mean May temperature, $1981-2010$ & Basinwide mean & ${ }^{\circ} \mathrm{C}$ & PRISM $^{8}$ \\
\hline Average mean June temperature, 1981-2010 & Basinwide mean & ${ }^{\circ} \mathrm{C}$ & PRISM $^{8}$ \\
\hline Average mean July temperature, 1981-2010 & Basinwide mean & ${ }^{\circ} \mathrm{C}$ & PRISM $^{8}$ \\
\hline Average mean August temperature, 1981-2010 & Basinwide mean & ${ }^{\circ} \mathrm{C}$ & PRISM $^{8}$ \\
\hline Average mean September temperature, 1981-2010 & Basinwide mean & ${ }^{\circ} \mathrm{C}$ & PRISM $^{8}$ \\
\hline Average mean October temperature, 1981-2010 & Basinwide mean & ${ }^{\circ} \mathrm{C}$ & PRISM $^{8}$ \\
\hline Average mean November temperature, 1981-2010 & Basinwide mean & ${ }^{\circ} \mathrm{C}$ & PRISM $^{8}$ \\
\hline Average mean December temperature, $1981-2010$ & Basinwide mean & ${ }^{\circ} \mathrm{C}$ & PRISM $^{8}$ \\
\hline Percent of basin that is lakes and ponds & Areal percent & Percent & $\mathrm{NWI}^{9}$ \\
\hline Percent of basin that is lakes, ponds, and swamps & Areal percent & Percent & $\mathrm{NWI}^{9}$ \\
\hline Percent of basin that is swamps & Areal percent & Percent & $\mathrm{NWI}^{9}$ \\
\hline Percent of basin that is wetland (palustrine, riverine, or lacustrine) & Areal percent & Percent & $\mathrm{NWI}^{9}$ \\
\hline Mean annual runoff & Basinwide mean & Inches & OFR $96-395^{10}$ \\
\hline Percent of basin covered by soil classified as drought-vulnerable soil & Areal percent & Percent & gSSURGO $^{11}$ \\
\hline Average available water storage in total soil profile & Basinwide mean & Millimeters & gSSURGO $^{11}$ \\
\hline Percent of basin with available water storage greater than 150 millimeters & Areal percent & Percent & gSSURGO $^{11}$ \\
\hline Average available water capacity & Basinwide mean & Inches per inch & STATSGO $^{12}$ \\
\hline Average liquid limit in percent soil moisture by weight & Basinwide mean & Percent & STATSGO $^{12}$ \\
\hline Basinwide mean of the STATSGO hydrologic character of soil classification & Basinwide mean & -- & STATSGO $^{12}$ \\
\hline
\end{tabular}


Table 2.1. Basin characteristics tested for use in the regression equations for estimating streamflow at ungaged sites with the Connecticut Streamflow and Sustainable Water Use Estimator.-Continued

[ft, foot; ${ }^{\circ} \mathrm{C}$, degrees Celsius; NED, National Elevation Dataset; WBD, Watershed Boundary Dataset; NHD, National Hydrography Dataset; NLCD, National Land Cover Database; PRISM, PRISM Climate Group; NWI, National Wetlands Inventory; gSSURGO, Gridded Soil Survey Geographic; STATSGO, State Soil Geographic; --, no data]

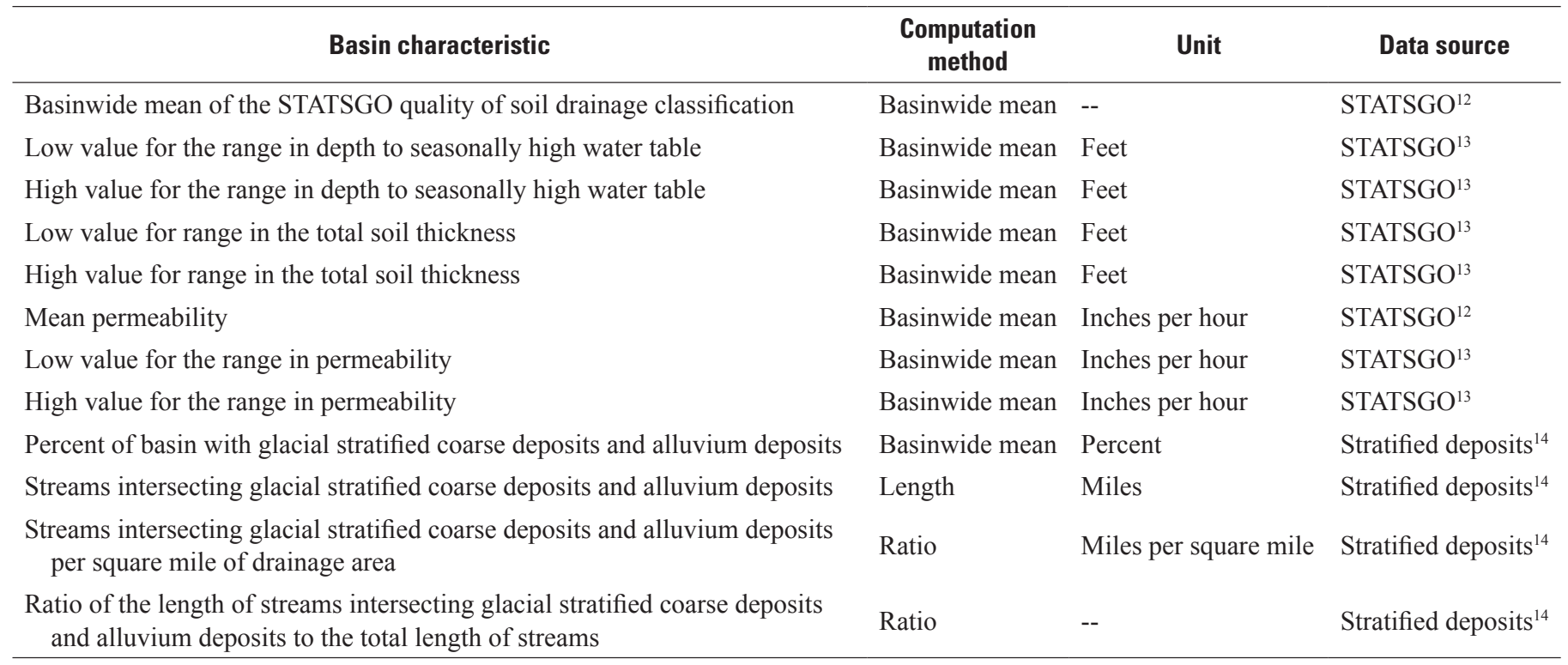

${ }^{1}$ U.S. Geological Survey (2017a).

${ }^{2}$ Natural Resources Conservation Service (2001).

${ }^{3}$ Fenneman and Johnson (1946).

${ }^{4}$ U.S. Geological Survey (2017b).

${ }^{5}$ Homer and others (2015).

${ }^{6}$ Xian and others (2011).

${ }^{7}$ Perica and others (2015).

${ }^{8}$ PRISM Climate Group (2012a, b).

${ }^{9}$ U.S. Fish and Wildlife Service (2016).

${ }^{10}$ Cohen and Randall (1998).

${ }^{11}$ Natural Resources Conservation Service (2014).

${ }^{12}$ U.S. Geological Survey (1995).

${ }^{13}$ Wolock (1997).

${ }^{14}$ Cadwell and others (1986), Connecticut Department of Environmental Protection (2009), Rhode Island Geographic Information System (1989), and U.S. Geological Survey (1999, 2015). 


\section{References Cited}

Cadwell, D.H., and others, 1986, Surficial geologic map of New York: New York State Museum Geological Survey Map and Chart Series 40, 1 sheet, scale 1:250,000, accessed March 20, 2017, at http://www.nysm.nysed.gov/ research-collections/geology/gis.

Cohen, A.J., and Randall, A.D., 1998, Mean annual runoff, precipitation, and evapotranspiration in the glaciated northeastern United States, 1951-80: U.S. Geological Survey Open-File Report 96-395, 1 p., 2 pls., accessed March 20, 2017, at https://water.usgs.gov/GIS/metadata/usgswrd/ XML/ofr96395 run.xml.

Connecticut Department of Energy and Environmental Protection, n.d., Water diversion program-Background: Connecticut Department of Energy and Environmental Protection web page, accessed May 15, 2017, at http://www.ct.gov/ deep/cwp/view.asp? $\mathrm{a}=2720 \& \mathrm{Q}=404928 \&$ deepNav_ $\mathrm{GID}=1654$.

Fenneman, N.M., and Johnson, D.W., 1946, Physiographic divisions of the conterminous U.S.: U.S. Geological Survey map, accessed March 20, 2017, at https://water.usgs.gov/ GIS/metadata/usgswrd/XML/physio.xml.

Homer, C.G., Dewitz, J.A., Yang, L., Jin, S., Danielson, P., Xian, G., Coulston, J., Herold, N.D., Wickham, J.D., and Megown, K., 2015, Completion of the 2011 national land cover database for the conterminous United States: Photogrammetric Engineering and Remote Sensing, v. 81, no. 5, p. 345-354, accessed March 17, 2017, at https://www.mrlc.gov/nlcd2011.php.

Natural Resources Conservation Service, 2001, Watershed boundary dataset, 1:24,000 scale: Natural Resources Conservation Service database, accessed March 17, 2017, at http://datagateway.nrcs.usda.gov/.

Natural Resources Conservation Service, 2014, Gridded soil survey geographic (gSSURGO) database, 10 meter resolution: Natural Resources Conservation Service database, accessed May 27, 2016, at http://datagateway.nrcs.usda.gov/.

Perica, S., Pavlovic, S., St. Laurent, M., Trypaluk, C., Unruh, D., Martin, D., and Wilhite, O., 2015, Precipitationfrequency atlas of the United States, vol. 10-Northeastern states (ver. 2.0): National Oceanic and Atmospheric Administration Atlas 14, accessed March 17, 2017, at http://hdsc.nws.noaa.gov/hdsc/pfds/pfds_gis.html.

PRISM Climate Group, Oregon State University, 2012a, United States average monthly or annual maximum temperature, 1981-2010, $4 \mathrm{~km}$ grid cell resolution, created July 10, 2012: Oregon State University digital data, accessed March 20, 2017, at http://www.prism.oregonstate.edu/.
PRISM Climate Group, Oregon State University, 2012b, United States average monthly or annual precipitation, 1981-2010, 30 arc-second normal, created July 10, 2012: Oregon State University digital data, accessed March 20, 2017, at http://www.prism.oregonstate.edu/.

Rhode Island Geographic Information System, 1989, Rhode Island glacial deposits, s44gg188: Rhode Island Geographic Information System Data Distribution System digital data, accessed March 20, 2017, at http://www.rigis.org/datasets/ glacial-deposits.

U.S. Fish and Wildlife Service, 2016, National wetlands inventory: U.S. Fish and Wildlife Service database, accessed May 27, 2016, at http://www.fws.gov/wetlands/.

U.S. Geological Survey, 1995, Soils data for the conterminous United States derived from the NRCS State soil geographic (STATSGO) data base (1.1 ed.): U.S. Geological Survey Open-File Report 95-449, accessed March 20, 2017, at https://water.usgs.gov/GIS/metadata/usgswrd/XML/ ussoils.xml.

U.S. Geological Survey, 1999, MassGIS data-Surficial geology (1:250,000): Massachusetts Office of Geographic Information digital data, accessed March 20, 2017, at http://www.mass.gov/anf/research-and-tech/it-serv-andsupport/application-serv/office-of-geographic-informationmassgis/datalayers/sg.html.

U.S. Geological Survey, 2015, MassGIS data-Surficial geology (1:24,000): Massachusetts Office of Geographic Information digital data, accessed March 20, 2017, at http://www.mass.gov/itd/sg24k.

U.S. Geological Survey, 2017a, National elevation dataset, 1 arc-second: U.S. Geological Survey database, accessed March 20, 2017, at https://ned.usgs.gov/.

U.S. Geological Survey, 2017b, National StreamStats program: U.S. Geological Survey web page, accessed March 17, 2017, at https://water.usgs.gov/osw/streamstats/.

Wolock, D.M., 1997, STATSGO soil characteristics for the conterminous United States: U.S. Geological Survey Open-File Report 97-656, accessed March 20, 2017, at http://water.usgs.gov/GIS/metadata/usgswrd/XML/ muid.xml.

Xian, G., Homer, C., Dewitz, J., Fry, J., Hossain, N., and Wickham, J., 2011, The change of impervious surface area between 2001 and 2006 in the conterminous United States. Photogrammetric Engineering and Remote Sensing, v. 77 , no. 8, p. 758-762, accessed March 17, 2017, at https://www.mrlc.gov/nlcd2011.php. 
Table 3.1. Dates of station record and dates of extended record for reference streamgages used by the Connecticut Streamflow and Sustainable Water Use Estimator.

[All streamgages are shown in figure 1. USGS, U.S. Geological Survey; MA, Massachusetts; RI, Rhode Island; CT, Connecticut; NY, New York; NA, not applicable]

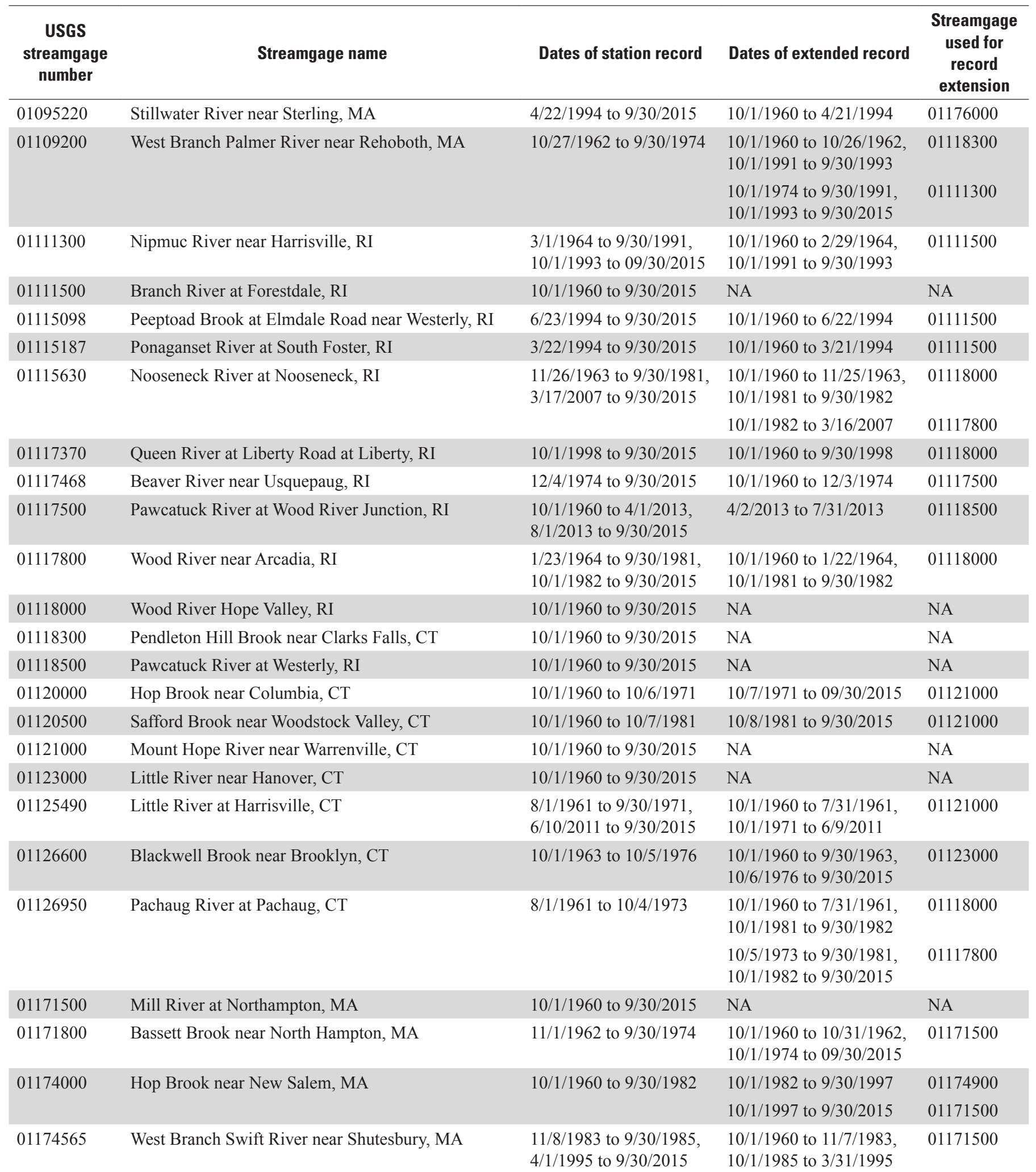


Table 3.1. Dates of station record and dates of extended record for reference streamgages used by the Connecticut Streamflow and Sustainable Water Use Estimator.-Continued

[All streamgages are shown in figure 1. USGS, U.S. Geological Survey; MA, Massachusetts; RI, Rhode Island; CT, Connecticut; NY, New York; NA, not applicable]

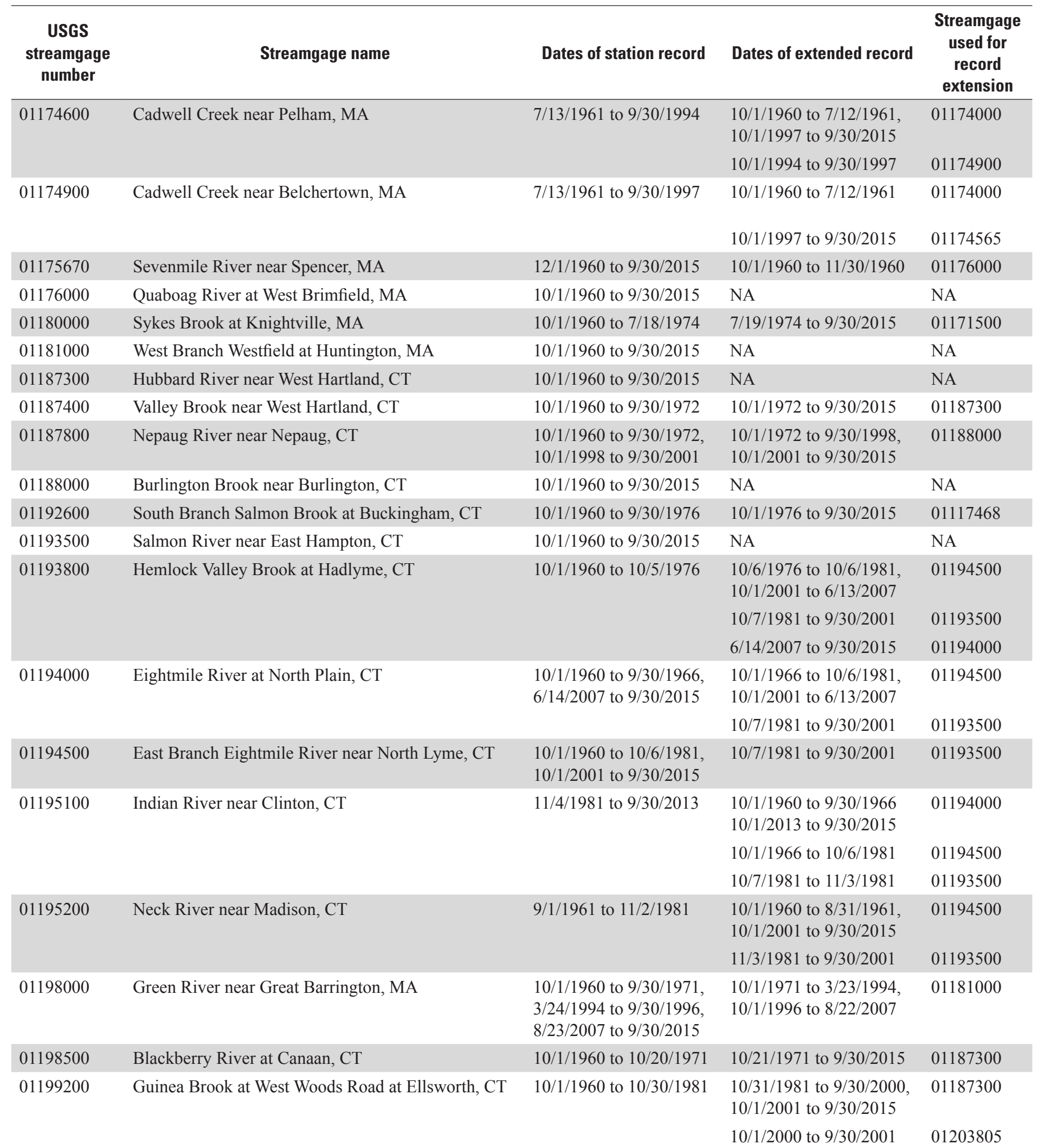


Table 3.1. Dates of station record and dates of extended record for reference streamgages used by the Connecticut Streamflow and Sustainable Water Use Estimator.-Continued

[All streamgages are shown in figure 1. USGS, U.S. Geological Survey; MA, Massachusetts; RI, Rhode Island; CT, Connecticut; NY, New York; NA, not applicable]

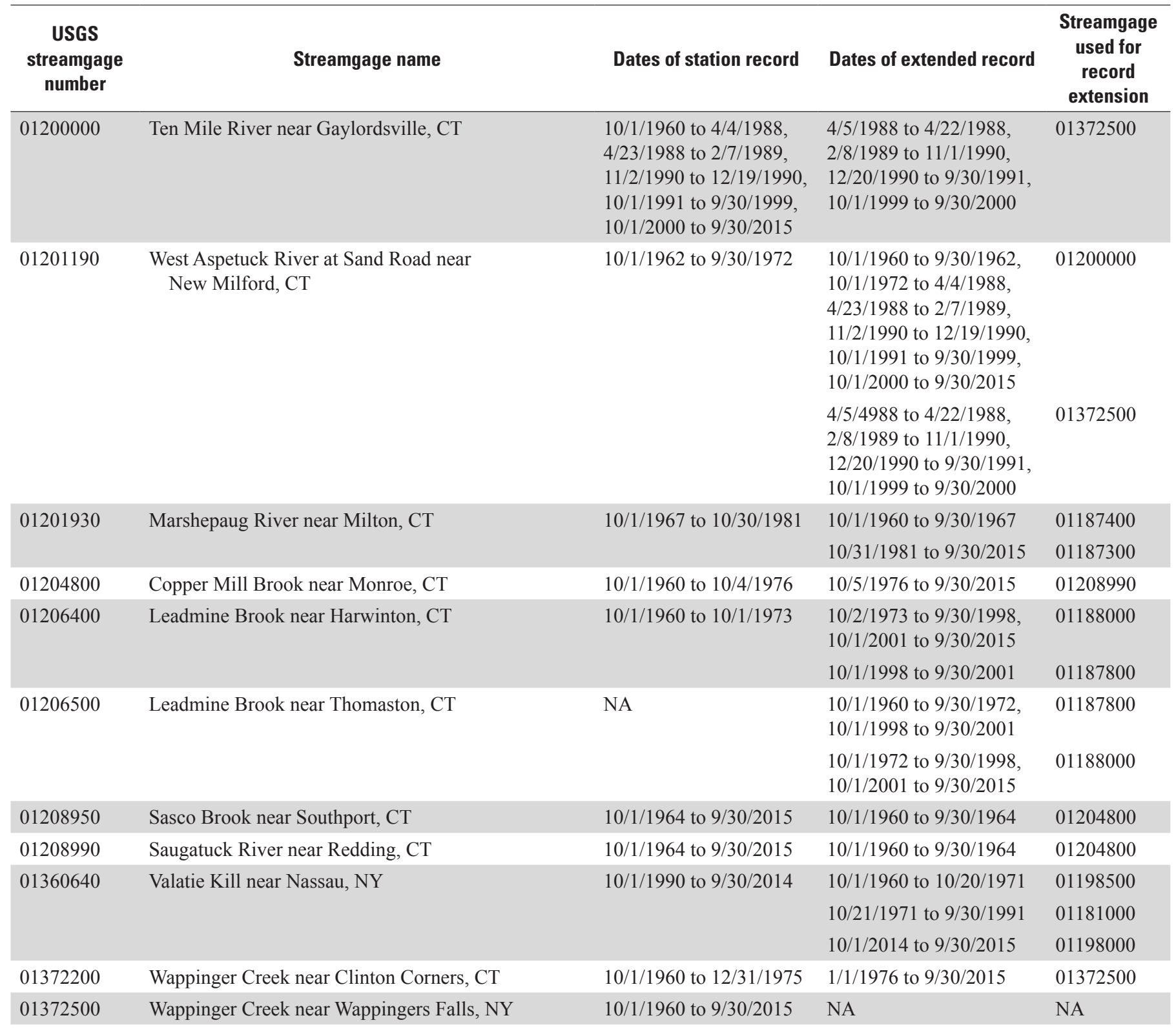


Table 3.1. Dates of station record and dates of extended record for reference streamgages used by the Connecticut Streamflow and Sustainable Water Use Estimator.-Continued

[All streamgages are shown in figure 1. USGS, U.S. Geological Survey; MA, Massachusetts; RI, Rhode Island; CT, Connecticut; NY, New York; NA, not applicable]

\begin{tabular}{|c|c|c|c|c|}
\hline $\begin{array}{c}\text { USGS } \\
\text { streamgage } \\
\text { number }\end{array}$ & Streamgage name & Dates of station record & Dates of extended record & $\begin{array}{c}\text { Streamgage } \\
\text { used for } \\
\text { record } \\
\text { extension }\end{array}$ \\
\hline 01372800 & & & $\begin{array}{l}2 / 8 / 1989 \text { to } 11 / 1 / 1990 \\
12 / 20 / 1990 \text { to } 9 / 30 / 1991 \\
10 / 1 / 1999 \text { to } 9 / 30 / 2000\end{array}$ & 01372500 \\
\hline 01374598 & & & $10 / 1 / 1964$ to $8 / 15 / 1996$ & 01208990 \\
\hline \multirow[t]{2}{*}{01374890} & Cross River near Cross River, NY & $12 / 8 / 1995$ to $9 / 30 / 2015$ & $10 / 1 / 1960$ to $9 / 30 / 1964$ & 01193500 \\
\hline & & & $10 / 1 / 1964$ to $12 / 7 / 1995$ & 01208990 \\
\hline \multirow[t]{2}{*}{01374987} & Kisco River below Mount Kisco, NY & $10 / 21 / 1995$ to $6 / 30 / 2009$ & $10 / 1 / 1960$ to $9 / 30 / 1964$ & 01193500 \\
\hline & & & $\begin{array}{l}10 / 1 / 1964 \text { to } 10 / 20 / 1995 \\
7 / 1 / 2009 \text { to } 9 / 30 / 2015\end{array}$ & 01208990 \\
\hline
\end{tabular}


For more information about this report, contact: Director, New England Water Science Center U.S. Geological Survey

10 Bearfoot Road

Northborough, MA 01532

dc_nweng@usgs.gov

or visit our website at

https://newengland.water.usgs.gov

Publishing support provided by the Pembroke Publishing Service Center 
焉.

흠

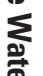

秥

罗

홀

흠 